\title{
Learning by Doing, Trade in Capital Goods
}

\author{
and Growth
}

\section{Ai-Ting Goh}

\section{Jacques Olivier*}

\begin{abstract}
$\underline{\text { Abstract }}$
This paper aims at reconciling theoretical models of endogenous growth with the empirical evidence on trade and growth. In particular, we show that the conventional wisdom according to which trade is growth-impairing for a country with comparative advantage in goods with limited opportunities for learning fails to hold when the imported good is a capital good. The intuition is that the country gains access to cheaper capital goods, which raises investment, output per worker and learning by doing.
\end{abstract}

Key words: Trade, capital goods, growth

JEL Classification: F10, O41

* Goh: National University of Singapore; Olivier: National University of Singapore, HEC School of Management and CEPR. Please send all correspondence to Ai-Ting Goh, Department of Economics, National University of Singapore, 10 Kent Ridge Crescent, Singapore 119260; e-mail: ecsgohat@ nus.edu.sg; fax: (65) 7752646.

We would like to thank Wilfred Ethier, Ulrich Hege, Lutz Hendricks, Boyan Jovanovic, Howard Pack, Paul Romer and especially Henry Wan as well as seminar participants at HEC, at the University of Louvain La Neuve, at the University of Pennsylvania, at the National University of Singapore and at the Far Eastern Meeting of the Econometric Society 1999 for helpful comments on a preliminary version of this paper. The second author gratefully acknowledges financial support from a HEC research grant. The usual disclaimer applies. 


\section{I) Introduction}

The last few decades, with the notable exception of the past year, have seen outwardoriented economies, most notably those in East Asia, grow at a more rapid pace than the rest of the world. Consequently, a huge body of empirical literature (see, for example, Levine and Renelt 1992, Harrison 1996, Frankel, Romer and Cyrus, 1996 and Edwards 1998) has looked at the link between openness to trade and output growth. Yet, theoretical models proposed so far all have major features that do not stand up well against the data. On the one hand, earlier models, such as Rivera-Batiz and Romer, (1991a) and (1991b) or Grossman and Helpman, (1991) can explain the observed link between trade and growth but rely on the existence of a scale effect. A larger stock of scientists in an integrated world generates more knowledge and hence faster growth. Unfortunately, recent empirical work based on time series strongly rejects the existence of such a scale effect (Jones, 1995$)^{1}$. On the other hand, models based on human capital (Stokey, 1991) or on learning by doing (Lucas, 1988, and Young, 1991) predict that an initially backward economy will grow at a slower rate than the rest of the world after opening up to trade, which is inconsistent with the Asian experience and, more generally, with the empirical evidence on trade and growth. The objective of this paper is to present a simple theoretical model that is consistent with the empirical evidence on trade and growth and to use the model to investigate how trade and trade policies affect long-run output growth.

We propose a much simplified model of trade and endogenous growth driven by learning by doing. The crucial difference with the existing literature is that we allow for capital goods to be traded while the existing literature looks only at trade in consumption goods. This

\footnotetext{
${ }^{1}$ See also Backus, Kehoe and Kehoe (1992).
} 
seemingly minor change is actually sufficient to reverse the conclusions of the existing literature. The conventional wisdom in models of open economies with learning by doing is that, "if the industries in which the less developed country has a static comparative advantage are industries in which there are limited opportunities for learning, then the effect of free trade is to speed up learning in the more developed country and to slow it down in the less developed one" (Stokey, 1991). In this paper however, we show that this conventional wisdom need not apply if the imported good is a capital good. Indeed, a country which has a comparative advantage in a low-learning consumption good but which gains access to cheaper capital goods under free-trade is able to accumulate more capital compared to autarky. This raises workers' productivity, output and learning by doing. Because of the interaction with learning by doing, the impact of capital accumulation on growth is permanent and can outweigh the negative effect of resources being reallocated toward a good with a lower potential for learning.

The model is a two-country (North and South), two-period overlapping generations model. Consumption and capital goods are distinct. New good designs arrive (exogenously) each period. Newer designs are cheaper to produce. North and South differ only in that North is "one generation ahead" of South. In other words, a good design of vintage t in North is available in South only from period $t+1$ onwards. As workers get to use new technologies, they learn to become more efficient. Their knowledge is then passed on to their children. Hence, there are two components to growth in this economy: technological progress, which for simplicity we assume to be exogenous, and learning by doing, which depends on production in the different sectors of the economy.

We first solve for a steady-state equilibrium under autarky. We then allow both countries 
to trade. We give conditions under which a balanced growth path, where North and South grow at the same rate, exists. The world growth rate is always higher under free trade than under autarky. Depending on parameter values, two types of balanced growth path can arise. In both cases, North exports capital goods and imports South's newest consumption good. We show that the impact of an export subsidy (import tariff) depends on the specialization pattern at the equilibrium. If South only is specialized, the policy raises (lowers) the world growth rate. On the other hand, if both countries are specialized, there is no effect of the export subsidy on growth but there is a positive level effect for South.

We contend that these results reconcile theory and evidence on trade and growth. Our model does not rely on any scale effect which is rejected by the data nor does it predict that developing countries fall behind developed countries after opening up to trade. The latter point is important for two reasons. First, and as already mentioned, there is a huge empirical literature demonstrating a positive impact of trade on growth in cross countries or panel data growth regressions. Second, an ever increasing gap between poor and rich countries is also inconsistent with, for instance, Parente and Prescott's (1993) observation that the gap between richest and poorest countries has remained constant in the last 25 years $^{2}$. These observations are both consistent with our model where a balanced growth path exists both under autarky and under free trade, and where the world growth rate is higher under free trade.

Furthermore, and maybe most importantly, there is direct empirical evidence supporting the importance of a capital accumulation effect in the link between trade and growth. Jones (1994) finds a strong significant positive correlation between price of machinery and growth.

\footnotetext{
${ }^{2}$ See also Jones (1997).
} 
Levine and Renelt (1992) looking at a cross section of countries find evidence of a two-link chain between trade and growth through investment and conclude that "the relationship between trade and growth may be based on enhanced resource accumulation and not necessarily on the improved allocation of resources" (p. 954). This finding is also confirmed by Harrison (1996) using panel data. Together, these results support our contention that countries that are more open to trade grow faster as they gain access to cheaper imported capital goods, accumulate more capital and hence are able to produce more output and generate more learning by doing.

The rest of the paper is organized as follows: In section II, we present the basic model. Section III we look at the effect of trade on growth when one of the traded good is a capital good. We show that there exists a balanced growth path equilibrium even if South exports a lower learning good under free-trade. The world growth rate is shown to be unambiguously higher under free-trade than under autarky. Section IV looks at the effect of an export subsidy. Section V concludes. Proofs are in the appendices.

\section{The Model}

The model is a two-country (North and South), two-period overlapping generations model. Each agent works in the first period but consumes during both periods. Population of both countries is constant and the size of each generation is normalized to one. ${ }^{3} \mathrm{We}$ first describe the production and consumption structures of the North and then proceed to describe the South.

\footnotetext{
${ }^{3}$ This last assumption can easily be relaxed as there is no scale effect in the economy.
} 
There are two factors of production, human capital (or effective labor) and physical capital. Each period, a new design of the consumption good and of the capital good are invented in North. Agents find consumption goods of different designs to be imperfectly substitutable to each other. On the other hand, new designs of the capital good are perfectly substitutable to the old ones. New designs are cheaper to produce and learning by doing occurs only when agents engage in the production of goods of newly arrived designs. We allow for different learning potentials of different goods. Finally, we assume perfect competition.

\section{A) $\underline{\text { North }}$}

\section{Production technology}

Production functions are Cobb-Douglas. Factor intensities are assumed to be the same across sectors. Production of new good designs is (exogenously assumed to be) more efficient: a unit of human capital devoted to the production of a good of vintage $t$ has the same productivity as $\phi(\phi>1)$ units of human capital devoted to the production of a good of vintage t-1. Thus, we have:

$$
\begin{aligned}
& Y_{k, t}^{N}=\left(\phi^{t} H_{k, t}^{N}\right)^{\alpha} K_{k, t}^{N}{ }^{1-\alpha} \\
& Y_{t, t}^{N}=\left(\phi^{t} H_{t, t}^{N}\right)^{\alpha} K_{t, t}^{N^{1-\alpha}} \\
& Y_{t-1, t}^{N}=\left(\phi^{t-1} H_{t-1, t}^{N}\right)^{\alpha} K_{t-1, t}^{N}{ }^{1-\alpha}
\end{aligned}
$$

The first subscript refers to the sector: $\mathrm{k}$ for capital, $\mathrm{t}$ for consumption good of vintage $\mathrm{t}$. The second subscript refers to time. The superscript indicates the country, where $\mathrm{N}$ stands for North and S for South. We assume that physical capital depreciates fully after one period 
so that the capital stock at time $t+1$ is equal to the savings of agents at time $\mathrm{t}^{4}$.

\section{Agent's problem}

Agents maximize their expected utility from consumption. Their utility function is assumed to be logarithmic in an index of consumption. The index of consumption is assumed to be Cobb-Douglas in the best two consumption good designs available. Hence, agents choose consumption and savings so as to:

$\operatorname{Max} \log \mathrm{c}_{\mathrm{t}-1, \mathrm{t}}^{\mathrm{N}} \mathrm{c}_{\mathrm{t}, \mathrm{t}}^{\mathrm{N}}{ }^{1-\varepsilon}+\beta \log \mathrm{c}_{\mathrm{t}, \mathrm{t}+1}^{\mathrm{N}} \mathrm{c}_{\mathrm{t}+1, \mathrm{t}+1}^{\mathrm{N}}{ }^{1-\varepsilon}$

s.t

$\mathrm{P}_{\mathrm{t}, \mathrm{t}}^{\mathrm{N}} \mathrm{c}_{\mathrm{t}, \mathrm{t}}^{\mathrm{N}}+\mathrm{P}_{\mathrm{t}-1, \mathrm{t}}^{\mathrm{N}} \mathrm{c}_{\mathrm{t}-1, \mathrm{t}}^{\mathrm{N}} \leq \mathrm{w}_{\mathrm{t}}^{\mathrm{N}} \mathrm{h}_{\mathrm{t}}^{\mathrm{N}}-\mathrm{P}_{\mathrm{k}, \mathrm{t}}^{\mathrm{N}} \mathrm{s}_{\mathrm{t}}^{\mathrm{N}}$

$\mathrm{P}_{\mathrm{t}+1, \mathrm{t}+1}^{\mathrm{N}} \mathrm{c}_{\mathrm{t}+1, \mathrm{t}+1}^{\mathrm{N}}+\mathrm{P}_{\mathrm{t}, \mathrm{t}+1}^{\mathrm{N}} \mathrm{c}_{\mathrm{t}, \mathrm{t}+1}^{\mathrm{N}} \leq \mathrm{P}_{\mathrm{k}, \mathrm{t}}^{\mathrm{N}} \mathrm{s}_{\mathrm{t}}^{\mathrm{N}} \mathrm{r}_{\mathrm{t}+1}^{\mathrm{N}}$

$c_{i, t}^{N}$ denotes the consumption of the good design which arrives in period $i, s_{t}$ saving and $h_{t}$

human capital. $\varepsilon$ is a positive constant less than 1 which measures the share of the old good design in the consumption of agents.

Note that these preferences are related to the preferences used in Stokey (1988) and Young (1991). Stokey and Young define preferences on the whole set of consumption good designs and derive conditions under which agents optimally choose to consume a finite number of designs. On the other hand, we exogenously impose the condition that agents consume only the two most recent designs of consumption goods. While this exogenous specification is much less appealing than Stokey's and Young's ${ }^{5}$, it still captures the idea that

\footnotetext{
${ }^{4}$ The main result of the paper can be shown not to depend on this assumption (proof available upon request), which allows us however to find closed form expressions.

${ }^{5}$ The main problem with the specification is that a necessary condition for agents to consume a finite number of goods is a finite marginal utility at zero, which is obviously not satisfied by logarithmic utilities.
} 
there may be some substitution between existing designs but that ultimately older designs become obsolete and disappear ${ }^{6}$. It also buys us two things. First, it allows us to work in an economy with only two traded goods while keeping the main feature of Young's model, namely that a new good in the South may already be a mature product in the North. Second, it allows us to obtain simple closed form solutions for the balanced growth path. Our hope is that both features make the intuition for our results more transparent.

Learning and the accumulation of human capital

We make four assumptions as far as learning by doing is concerned:

\section{Assumption 1.:}

Young agents inherit the human capital of their parents.

\section{Assumption 2::}

Agents' human capital increases only when they produce a good of a design newly arrived in their country.

\section{Assumption 3.:}

The rate at which an agent's human capital increases depends on the output he produces in the high-learning sectors. This is similar to Lucas (1988) and Young (1991). The learning function is assumed to be of the form:

$$
\frac{H_{t+1}^{N}-H_{t}^{N}}{H_{t}^{N}}=\left(a_{c} \frac{Y_{t, t}^{N}}{\phi^{t} H_{t}^{N}}+a_{k} \frac{Y_{k, t}^{N}}{\phi^{t} H_{t}^{N}}\right)^{\delta}
$$

\footnotetext{
${ }^{6}$ A good example of this is personal computers. Even if you use, say, only word processors and would prefer to buy a cheap 386 to a more expensive Pentium, you will have a hard time finding a 386 in any computer store. A similar example are clothes that you may like but that have gone out of fashion.
} 
where $\mathrm{H}_{t+1}^{\mathrm{N}}$ is the total stock of human capital inherited by young agents born at time $t+1$ and $\mathrm{H}_{\mathrm{t}}^{\mathrm{N}}$ is the initial human capital of their parents. $\mathrm{a}_{\mathrm{c}}, \mathrm{a}_{\mathrm{k}}$, and $\delta$ are positive constants. Note that the rate at which human capital grows does not depend on the size of the economy as we have normalized the RHS of equation (4) by the total quantity of human capital in the economy, $\phi^{t} H_{t}$. Such a specification is necessary to eliminate the scale effects present in many learning-by-doing models (see, for instance, Jovanovic 1995).

\section{Assumption 4.:}

The learning coefficient in the capital good sector is at least as high as that in the consumption good sector, that is, $\mathrm{a}_{\mathrm{k}} \geq \mathrm{a}_{\mathrm{c}}$.

Assumption 4 means that there is more learning taking place in the production of capital goods than in the production of consumption goods. It is justified by the observation that the capital goods industry is more skilled labor intensive than the consumption good industry and that learning is more important for skill-intensive production processes (Amsden, 1986). It also corresponds to the case generally studied by the existing theoretical literature, where the developing country has a comparative advantage in a good with limited opportunities for learning (cf. Remark 1 below).

\section{2) South}

The developing country, South, is similar to the developed country, North, in every aspect except that it is one generation behind, in the sense that new good designs are available in the South only one period after they arrived in the North. In other words, Southern producers can produce a good design of vintage $t$ only from period $t+1$ onwards 
and Southern consumers can consume a good design of vintage $t$ only from period $t+1$ onwards. The production lag captures the time required for the technology of production of the new designs to be transfered from North to South. ${ }^{7}$ The consumption lag captures the need for infrastructures to be built and the necessity for Northern producers to standardize the good to suit the needs of Southern consumers. For simplicity, we assume that production and consumption lags are the same and equal to one period ${ }^{8}$.

At time $t$, South produces capital good design of vintage $t-1^{9}$ and consumption good designs of vintages $\mathrm{t}-1$ and $\mathrm{t}-2$. The production function is the same as in North. Hence:

$$
\begin{aligned}
& Y_{k, t}^{S}=\left(\phi^{t-1} H_{k, t}^{S}\right)^{\alpha} K_{k, t}^{S}{ }^{1-\alpha} \\
& Y_{t-1, t}^{S}=\left(\phi^{t-1} H_{t-1, t}^{S}\right)^{\alpha} K_{t-1, t}^{S}{ }^{1-\alpha} \\
& Y_{t-2, t}^{S}=\left(\phi^{t-2} H_{t-2, t}^{S}\right)^{\alpha} K_{t-2, t}^{S}{ }^{1-\alpha}
\end{aligned}
$$

At time t, agents in South consume good designs of vintages t-1 and t-2. Preferences are the same as in North. Hence, agents solve:

$$
\begin{aligned}
& \operatorname{Max} \log \mathrm{c}_{\mathrm{t}-2, \mathrm{t}}^{\mathrm{s}} \mathrm{c}_{\mathrm{t}-1, \mathrm{t}}^{\mathrm{s}}{ }^{1-\varepsilon}+\beta \log \mathrm{c}_{\mathrm{t}-1, \mathrm{t}+1}^{\mathrm{s}} \mathrm{c}_{\mathrm{t}, \mathrm{t}+1}^{\mathrm{s}}{ }^{1-\varepsilon} \\
& \mathrm{s} . \mathrm{t} \\
& \mathrm{P}_{\mathrm{t}-1, \mathrm{t}}^{\mathrm{S}} \mathrm{c}_{\mathrm{t}-1, \mathrm{t}}^{\mathrm{S}}+\mathrm{P}_{\mathrm{t}-2, \mathrm{t}}^{\mathrm{S}} \mathrm{c}_{\mathrm{t}-2, \mathrm{t}}^{\mathrm{S}} \leq \mathrm{w}_{\mathrm{t}}^{\mathrm{S}} \mathrm{h}_{\mathrm{t}}^{\mathrm{S}}-\mathrm{P}_{\mathrm{k}, \mathrm{t}}^{\mathrm{S}} \mathrm{s}_{\mathrm{t}}^{\mathrm{S}} \\
& \mathrm{P}_{\mathrm{t}, \mathrm{t}+1}^{\mathrm{S}} \mathrm{c}_{\mathrm{t}, \mathrm{t}+1}^{\mathrm{S}}+\mathrm{P}_{\mathrm{t}-1, \mathrm{t}+1}^{\mathrm{S}} \mathrm{c}_{\mathrm{t}-1, \mathrm{t}+1}^{\mathrm{S}} \leq \mathrm{P}_{\mathrm{k}, \mathrm{t}}^{\mathrm{S}} \mathrm{s}_{\mathrm{t}}^{\mathrm{S}} \mathrm{r}_{\mathrm{t}+1}^{\mathrm{S}}
\end{aligned}
$$

The learning function in South is the same as in North:

\footnotetext{
${ }^{7}$ See Vernon (1996) for empirical evidence, Krugman (1979) for a model of North-South technology transfer. ${ }^{8}$ The assumption of the existence of a consumption lag can easily be released without affecting the results of the paper (proof available upon request). The existence of a production lag gives room for trade to arise between North and South. See Remark 1 below.

${ }^{9}$ Since the capital goods of different designs are perfectly substitutable, we always use the subscript $k$ regardless of the vintage of the capital good.
} 
$\frac{H_{t+1}^{S}-H_{t}^{S}}{H_{t}^{S}}=\left(a_{c} \frac{Y_{t-1, t}^{S}}{\phi^{t-1} H_{t}^{S}}+a_{k} \frac{Y_{k, t}^{S}}{\phi^{t-1} H_{t}^{S}}\right)^{\delta}$

To summarize, we have the following production and consumption patterns in the two countries:

$\mathrm{N}: \quad \mathrm{k}, \mathrm{t}, \mathrm{t}-1 \quad \mathrm{k}, \mathrm{t}+1, \mathrm{t}$

$\mathrm{S}: \quad \mathrm{k}, \mathrm{t}-1, \mathrm{t}-2 \quad \mathrm{k}, \mathrm{t}, \mathrm{t}-1$

At any time t, North and South produce only one consumption good design in common, namely, vintage $\mathrm{t}-1$. To save on notations, we will from now on refer to the two consumption good designs consumed by Northern agents respectively as the high- and medium- quality designs, and to the two good designs consumed by Southern agents as the medium- and lowquality designs. Recall however, that the high quality design at time $t$ becomes the medium quality design at time $\mathrm{t}+1$. Notice also that, given the production and consumption patterns above, if trade is to take place between the two countries, it necessarily involves the exchange of the common consumption good design t-1 for the capital good. Hence, the high quality and the low quality good designs remain non-traded. ${ }^{10}$

Remark 1: North has a comparative advantage in the production of capital goods while South has a comparative advantage in the production of the medium quality consumption good design.

Proof: Let $C_{i, t}^{j}\left(w^{j}, r^{j}\right)$ be the unit cost of producing good $i$ in country $j$. Then,

\footnotetext{
${ }^{10}$ This feature corresponds to empirical evidence as documented by Keesing and Lall (1992) and Egan and Mody (1992) that developing countries export only their highest quality goods.
} 
(1) and (3) $\Rightarrow \frac{\mathrm{C}_{\mathrm{k}, \mathrm{t}}^{\mathrm{N}}\left(\mathrm{w}^{\mathrm{N}}, \mathrm{r}^{\mathrm{N}}\right)}{\mathrm{C}_{\mathrm{t}-1, \mathrm{t}}^{\mathrm{N}}\left(\mathrm{w}^{\mathrm{N}}, \mathrm{r}^{\mathrm{N}}\right)}=\frac{1}{\phi^{\alpha}}<1$

(5) and (6) $\Rightarrow \frac{\mathrm{C}_{\mathrm{k}, \mathrm{t}}^{\mathrm{S}}\left(\mathrm{w}^{\mathrm{S}}, \mathrm{r}^{\mathrm{s}}\right)}{\mathrm{C}_{\mathrm{t}-1, \mathrm{t}}^{\mathrm{S}}\left(\mathrm{w}^{\mathrm{S}}, \mathrm{r}^{\mathrm{s}}\right)}=1$

Note that by Assumption 4, Remark 1 implies that South has a comparative advantage in the low learning good. According to the existing literature, this should imply that South necessary grows slower under free trade than under autarky since it is importing a high learning good and exporting a low learning good. The contention of this paper is that such a conclusion is not warranted when the high learning good is a capital good. By engaging in trade, South gains access to cheaper capital goods and thus is able to enjoy a higher level of investment, output per worker and hence, learning by doing, in the consumption good sector.

\section{Effects of Trade on Growth: Direct and Capital Accumulation Effects}

In this section we study the effect of trade on growth when one of the traded goods is a capital good. We first solve for the autarky equilibrium and then compare the autarky eqilibrium to the free trade equilibrium.

\section{$\underline{\text { A) Autarky Equilibrium }}$}

Since the autarky equilibrium can be solved using straightforward techniques, we have restricted all details of the proof to the appendix. We first define a balanced growth path equilibrium under autarky as an equilibrium where interest rate as well as growth rates of output, capital and wages are constant over time: 


\section{Definition 1:}

A balanced growth path equilibrium under autarky is a competitive equilibrium such that:

(i) The interest rate is constant.

(ii) $H_{t}$ grows at constant rate $\mathrm{g}_{\mathrm{H}}^{\mathrm{A}}$, output and capital grow at constant rate $\phi+\mathrm{g}_{\mathrm{H}}^{\mathrm{A}}$, wages grow at constant rate $\phi$

In Appendix A, we show the existence of and characterize the balanced growth path under autarky of this economy. The results are summarized in Proposition 1 below:

\section{Proposition 1:}

There exists a balanced growth path of both economies under autarky. The equilibrium growth rate of human capital is the same in both economies and is implicitly defined by:

$$
\left(\mathrm{g}_{\mathrm{H}}^{\mathrm{A}}\right)^{\frac{1}{\delta}}\left(1+\mathrm{g}_{\mathrm{H}}^{\mathrm{A}}\right)^{\frac{1-\alpha}{\alpha}}=\left(\frac{\alpha}{\phi} \frac{\beta}{1+\beta}\right)^{\frac{(1-\alpha)}{\alpha}}\left\{\mathrm{a}_{\mathrm{c}}\left[\frac{(1-\varepsilon) \alpha}{1+\beta}+(1-\varepsilon)(1-\alpha)\right]+\mathrm{a}_{\mathrm{k}} \frac{\alpha \beta}{1+\beta}\right\}
$$

Proof: See Appendix A.

Along the steady state autarky growth path, output and capital grow at rate $\phi+\mathrm{g}_{\mathrm{H}}^{\mathrm{A}}$. There are two components to the growth rate, $\phi$ is the exogenous rate of technological progress while $\mathrm{g}_{\mathrm{H}}^{\mathrm{A}}$ is an endogenous component coming from learning by doing. The higher is the output of the newest goods, the more learning there is, and the faster the economy grows. Equation (9) uniquely characterizes this endogenous component.

We are now ready to analyze the equilibrium under free trade. Two main questions need to be answered. First, whether there still exists a balanced growth path equilibrium after trade 
or whether the output of both countries must necessarily diverge. Second, given that there exists a balanced growth path, whether the world growth rate is smaller or larger than under autarky. We address these questions in the next section.

\section{B) Free trade equilibrium}

We now allow for trade between the two countries. The high quality design is not available for consumption in South while the low-quality design is not desired by Northern agents $^{11}$. Since the relative cost of production of consumption goods of medium quality design with respect to capital good is lower in South, South exports consumption goods of medium quality design in exchange for capital goods.

Note that while this structure of trade is simplistic, it captures some of the main stylized facts concerning trade patterns between developing and developed countries. First, it is observed that developing countries exchange consumption goods for capital goods. Between 1980 and 1989, the share of machinery and transport equipment in total exports from developed to developing countries was constantly over $40 \%$. By contrast, the same share in the exports from developing to developed countries has been around 5 - $10 \%$ for many years and only recently reached $20 \%$ (Source: GATT, 1990). Second, developing countries tend to export their highest quality consumption goods (see Keesing and Lall, 1992 or Egan and Mody, 1992). The pattern of trade in our economy, unlike that of many existing models of trade and growth, captures both these observations.

We first define a balanced growth path equilibrium of an open economy.

\footnotetext{
${ }^{11}$ As indicated earlier in the paper, both assumptions can easily be relaxed without changing the qualitative results of the paper but at the cost of losing closed form solutions.
} 


\section{Definition 2:}

A balanced growth path equilibrium under free trade is a competitive equilibrium such that:

(i) Interest rates are constant in both countries.

(ii) Trade is balanced

(iii) In both North and South, human capital grows at the same constant rate $\mathrm{g}_{\mathrm{H}}^{\mathrm{T}}$, output and capital grow at the constant rate $\phi+\mathrm{g}_{\mathrm{H}}^{\mathrm{T}}$, wages grow at the constant rate $\phi$.

In Appendix A, we show that two types of balanced growth path can arise. They are distinguished by the specialization pattern at the equilibrium. We first define what we mean by complete specialization in our framework and then state the main result of the paper:

\section{Definition 3}

South is said to be completely specialized if $\mathrm{Y}_{\mathrm{k}, \mathrm{t}}^{\mathrm{S}}$ is equal to zero, and North is completely specialized if $\mathrm{Y}_{\mathrm{t}-1, \mathrm{t}}^{\mathrm{N}}$ is equal to zero, at the trading equilibrium.

\section{Proposition 2}

(i): There exists a balanced growth path equilibrium under free trade iff:

$$
\frac{\mathrm{a}_{\mathrm{k}}}{\mathrm{a}_{\mathrm{c}}}<1+\frac{\left(1-\varepsilon+\frac{\alpha \beta}{1+\beta} \varepsilon\right)\left(\phi^{1-\alpha}-1\right)}{\frac{\alpha \beta}{1+\beta}}
$$

(ii): Furthermore:

South only is completely specialized at the equilibrium iff:

$$
1+\frac{\left[1-\varepsilon\left(1-\frac{\alpha \beta}{1+\beta}\right)\right] \phi^{1-\alpha}-1}{\frac{\alpha \beta}{1+\beta}+\left(1-\frac{\alpha \beta}{1+\beta}\right) \varepsilon}<\frac{a_{k}}{a_{c}}<1+\frac{\left(1-\varepsilon+\frac{\alpha \beta}{1+\beta} \varepsilon\right)\left(\phi^{1-\alpha}-1\right)}{\frac{\alpha \beta}{1+\beta}}
$$


Both countries are specialized iff:

$\frac{\mathrm{a}_{\mathrm{k}}}{\mathrm{a}_{\mathrm{c}}} \leq 1+\frac{\left[1-\varepsilon\left(1-\frac{\alpha \beta}{1+\beta}\right)\right] \phi^{1-\alpha}-1}{\frac{\alpha \beta}{1+\beta}+\left(1-\frac{\alpha \beta}{1+\beta}\right) \varepsilon}$

(iii): The world growth rate is higher than under autarky in both cases.

Proof: See Appendix A

Proposition 2 states two important results. First, it says that even though South is specialized in a good with lower learning opportunities, there may still exist a balanced growth path. The assumption driving this result is that the good imported by South is a capital good. The intuition is as follows: North imports medium quality goods and exports capital goods. Hence Northern resources are being reallocated from the medium quality good sector, which does not contribute to Northern agents' learning, to the capital goods sector, which is a high-learning sector. Hence North grows faster under free-trade. On the other hand, South imports a high-learning good and exports a low-learning good. Consequently, free trade leads to a reallocation of resources away from the activities with the most learning for South. We call this the direct effect. If countries were to trade only in consumption goods, this would be the only effect that would be present and South would grow at a slower rate than North. This effect is the only effect present in the existing literature where only consumption goods are traded. However, another effect comes into the picture where capital goods are traded: capital goods are cheaper under free trade than under autarky for South. Hence, agents accumulate more capital, resulting in higher capital/labor ratio and output per worker. This implies that more learning by doing occurs, which pushes up the growth rate of 
South. As long as the direct effect is not too strong (i.e. $\mathrm{a}_{\mathrm{k}} / \mathrm{a}_{\mathrm{c}}$ not too large), the existence of this second effect, which we call the capital accumulation effect, is sufficient to guarantee the existence of a balanced growth path under free trade. ${ }^{12}$

The second important result in Proposition 2 is the fact that the world growth rate is unambiguously higher under free trade than under autarky. This is not surprising: North always benefits from trade because of the direct effect. Trade enables North to reallocate resources away from a sector where all possibilities of learning have been exhausted and into a new sector. Hence, if a balanced growth path under free trade exists at all, it must necessarily be such that South is also growing at a faster rate than under autarky.

The final result in Proposition 2 is that two types of equilibria can exist, depending on the specialization pattern at the equilibrium. The first type of equilibrium occurs when $a_{k} / a_{c}$ is large, that is, learning externalities are much stronger in the capital good sector as compared to the consumption good sector. This means that the direct effect is strong. For a balanced growth path to exist after trade, South needs to be completely specialized so that the relative price of capital goods under free trade is at its lowest possible, that is, at North's autarky prices. As a consequence, the capital accumulation effect is at its strongest and outweighs the direct effect for South at the equilibrium. When the direct effect is weaker, i.e. when $a_{k} / a_{c}$ is smaller, a different type of equilibrium, where North is completely specialized as well, arises. In this case, the equilibrium world price of capital is larger than in the case where South only is specialized and the capital accumulation effect is weaker as well.

\footnotetext{
${ }^{12}$ Note that capital accumulation affects the growth rate of output on the balanced growth path only because of the interaction with learning by doing. Otherwise, decreasing returns would kick in and there would be no permanent growth effect.
} 
Finally, it is important to point out that the relative size of both countries is uniquely determined at the equilibrium (and can be found in Appendix A). This is an important feature of the model that allows us to discuss the level effects of trade policies in Section IV. To understand this feature, it is useful to recall the expressions for the equilibrium growth rates in both North and South in the case where South only is specialized. In Appendix A, we show that the equilibrium growth rate of South is given by:

$$
\left(\mathrm{g}_{\mathrm{H}}^{\mathrm{S}, \mathrm{T}}\right)^{\frac{1}{\delta}}\left(1+\mathrm{g}_{\mathrm{H}}^{\mathrm{S}, \mathrm{T}}\right)^{\frac{1-\alpha}{\alpha}}=\mathrm{a}_{\mathrm{c}}\left[(1-\varepsilon)+\frac{\varepsilon \alpha \beta}{1+\beta}\right]\left(\frac{\alpha}{\phi} \frac{\beta}{1+\beta}\right)^{\frac{1-\alpha}{\alpha}} \phi^{1-\alpha}
$$

whereas North's growth rate is given by Equation (11) below:

$$
\left(\mathrm{g}_{\mathrm{H}}^{\mathrm{N}, \mathrm{T}}\right)^{\frac{1}{\delta}}\left(1+\mathrm{g}_{\mathrm{H}}^{\mathrm{N}, \mathrm{T}}\right)^{\frac{1-\alpha}{\alpha}}=\left(\frac{\alpha}{\phi} \frac{\beta}{1+\beta}\right)^{\frac{1-\alpha}{\alpha}}\left\{\mathrm{a}_{\mathrm{c}}\left[\frac{(1-\varepsilon) \alpha}{1+\beta}+(1-\varepsilon)(1-\alpha)\right]+\mathrm{a}_{\mathrm{k}} \frac{\alpha \beta}{1+\beta}\left(1+\frac{\mathrm{H}_{\mathrm{t}}^{\mathrm{S}}}{\mathrm{H}_{\mathrm{t}}^{\mathrm{N}}}\right)\right\}
$$

One can easily check that the relative size of both countries enters North's growth equation (11). Indeed, the magnitude of the direct effect depends on the volume of trade. The larger is the volume of trade, the more resources are being reallocated from the importable sector to the exportable sector. Thus, the larger South is compared to the North, the larger is the volume of trade, and the stronger is the direct effect for North. On the other hand, South's growth rate is independent of relative sizes. Indeed, the direct effect is already at its strongest as far as South is concerned (because of complete specialization, there are no resources used in the production of capital goods), and the capital accumulation effect solely depends on the free trade equilibrium price of the capital good which is equal to North's autarky price but not on the volume of trade.

Hence, the system of equations $\{(10),(11)\}$ which describes the equilibrium allocations 
has two endogenous variables, the world growth rate and the relative size of North versus South in the long run. There exists a balanced growth path equilibrium if and only if there exists a positive relative size such that both countries are growing at the same rate. Proposition 2 above characterizes the set of parameters such that there exists a positive solution to the system above and shows that the world growth rate is always higher under free-trade than under autarky.

Turning now to empirical evidence, we contend that the capital accumulation effect which is at play in Proposition 2 is a very natural candidate for explaining the observed relationship between trade and growth. Jones (1994) finds a significant negative relationship between output growth and relative price of machinery. Levine and Renelt (1992) point out that while exports, imports and total trade variables all come significant in growth regressions, the same trade indicators become non significant once one controls for the share of investment in GDP. Furthermore, they also show that the share of trade in GDP is significantly positively correlated with the share of investment. They conclude from these three observations that their results "indicate that the relationship between trade and growth may be based on enhanced resource accumulation and not necessarily on the improved allocation of resources" (p. 954) while "interestingly, however, the theoretical ties between growth and trade seem to run through improved resource allocation and not through a higher physical investment share" (p. 955). Levine and Renelt's findings are also confirmed by Harrison (1996) who finds that the same positive relationship between trade shares and investment share in GDP ${ }^{13}$ in a panel data study.

\footnotetext{
${ }^{13}$ Note however that while Harrison shows that the relationship between trade share and investment is extremely robust, it is less so for other indicators of openness.
} 
A good example illustrating the importance of the impact of trade on resource accumulation is that of India. India has put a heavy emphasis on the development of a local capital good industry under protection. As shown by Lall (1985), significant learning took place in this industry. According to traditional models of learning by doing, protecting a highlearning industry should have led to faster growth. Yet, India's industrial performance has fallen sharply behind that of the East-Asian NIEs that imported considerable quantities of equipment from abroad. We suggest that one of the major economic forces explaining these two different growth experiences is the capital accumulation effect: because of free-trade, the East-Asian economies had access to cheaper capital goods than India and were thus able to grow faster.

\section{Trade Policies}

In this section, we discuss the effects of an export subsidy policy by South. Under this scenario, for each dollar worth (local prices) of consumption good exported, South gives firms a $s$ dollars subsidy. This subsidy is financed by income taxes. As we wish to abstract from redistributive considerations, we assume that a proportional income tax $\mathrm{d}(\mathrm{s})$ is levied on agents. This tax leaves the relative distribution of income unchanged. The same exercise applies to export taxes (the case where $s$ is negative) which are used to finance a proportional transfer. It also applies to import tariffs since, in our model, imposing an import tariff has the same effect as imposing an export tax. ${ }^{14}$

We first look at the case where South only is specialized. In this case, we show that an

\footnotetext{
${ }^{14}$ This is because factor intensities are the same in all sectors, which implies that the relative price of traded versus non-traded consumption good is constant and equal to the ratio of total factor productivities.
} 
export subsidy unambiguously raises the world growth rate. Indeed, North grows faster because of the direct effect as the export subsidy increases the volume of trade. South grows faster as well because it imports more capital goods, thus increasing worker's productivity and learning. On the other hand, the effect on the relative size of North and South is ambiguous. In Appendix B, we prove the following proposition:

\section{Proposition 3:}

(i): There exists a balanced growth path equilibrium where:

- South only is specialized

- South adopts a proportional export subsidy rate s financed by a proportional income tax

iff: $\frac{a_{k}}{a_{c}}>1+\frac{\left(\frac{\phi^{\alpha}(1+\beta)}{\alpha s \beta+(1-s)(1+\beta)}\right)^{\frac{1-\alpha}{\alpha}}\left[1-\varepsilon \frac{(1-s)(1+\beta)}{\alpha s \beta+(1-s)(1+\beta)}\left(1-\frac{\alpha \beta}{1+\beta}\right)\right]-1}{\frac{\alpha \beta}{1+\beta}+\varepsilon\left(1-\frac{\alpha \beta}{1+\beta}\right)}$

and: $\frac{\mathrm{a}_{\mathrm{k}}}{\mathrm{a}_{\mathrm{c}}}<1+\frac{\left(\frac{\phi^{\alpha}(1+\beta)}{\alpha \mathrm{s} \beta+(1-\mathrm{s})(1+\beta)}\right)^{\frac{1-\alpha}{\alpha}}\left[1-\varepsilon \frac{(1-\mathrm{s})(1+\beta)}{\alpha s \beta+(1-\mathrm{s})(1+\beta)}\left(1-\frac{\alpha \beta}{1+\beta}\right)\right]-\left[1-\varepsilon\left(1-\frac{\alpha \beta}{1+\beta}\right)\right]}{\frac{\alpha \beta}{1+\beta}}$

(ii): The world growth rate is higher than under free-trade.

(iii): Furthermore, if we define: $R(s) \equiv \frac{H^{S}}{H^{N}}(s)$, then:

a) $R^{\prime}(0)>0$ iff: $\quad \phi^{1-\alpha}<\frac{\mathrm{a}_{\mathrm{c}}(1-\varepsilon)\left(1-\frac{\alpha \beta}{1+\beta}\right)+\mathrm{a}_{\mathrm{k}} \frac{\alpha \beta}{1+\beta}}{\mathrm{a}_{\mathrm{c}} \alpha(1-\varepsilon)}$

b) $R^{\prime \prime}(s)<0$

Proof: See Appendix B 
A subsidy raises the world growth rate because resources are not allocated efficiently ${ }^{15}$ across countries at the free trade equilibrium. North keeps producing the intermediate consumption good even though learning has already been exhausted. An export subsidy increases the volume of trade and reallocates resources more efficiently across countries: North produces less of the intermediate consumption good and more of the capital good. Hence an export subsidy by South is growth enhancing when South only is completely specialized. On the other hand, in terms of levels, which country benefits the most from the subsidy is unclear. Part (iii) of Proposition 3 gives a condition on parameter values for which the size of South relative to North goes up with the introduction of a small export subsidy.

It is important to point out that Proposition 3 has drastically different policy implications from earlier work on models of learning by doing and trade. The policy recommendation of Lucas (1988) is to "pick winners" (namely goods with a high potential for learning) and subsidize their production. What Proposition 3 tells us is that subdizing the export of a low learning good may nevertheless raise the country's growth rate if by so doing the country's capital/ labor ratio increases. Obviously, such an effect can not be captured in a model where labor is the only factor of production and capital goods do not exist.

We now turn to the equilibrium where both North and South are specialized. In Appendix $B$, we prove the following:

\section{Proposition 4:}

(i): There exists a balanced growth path where

- both North and South are specialized

15 "Efficiently" is used here in the sense of "growth maximizing" and not as "welfare maximizing". 
- South adopts a proportional export subsidy rate s financed by a proportional income tax

iff: $\frac{a_{\mathrm{k}}}{\mathrm{a}_{\mathrm{c}}} \leq 1+\frac{\left(\frac{(1+\beta)}{\alpha s \beta+(1-\mathrm{s})(1+\beta)}\right)^{\frac{1-\alpha}{\alpha}} \phi^{1-\alpha}\left[1-\varepsilon \frac{(1-\mathrm{s})(1+\beta)}{\alpha s \beta+(1-s)(1+\beta)}\left(1-\frac{\alpha \beta}{1+\beta}\right)\right]-1}{\left[\frac{\alpha \beta}{1+\beta}+\varepsilon\left(1-\frac{\alpha \beta}{1+\beta}\right)\right]}$

(ii): The world growth rate is the same as under free trade.

(iii): The relative size of South is larger than under free trade.

What happens in the case where both countries are specialized is quite different from the case where South only is specialized. South's export subsidy now has a price effect that it did not have before. When South tries to implement an export subsidy policy to benefit from the capital accumulation effect, world prices adjust. In the steady-state North's exports are the same as under free-trade. Hence, North allocates resources in the same way and grows at the same rate. On the other hand, since the income tax lowers the demand for the old consumption good while the subsidy raises the demand for exports, South reallocates resources from the (low-learning) non-traded good sector to the (high-learning) export sector. At first South grows faster than North and hence becomes larger. This leads to a change in the terms of trade against South thus reducing the capital accumulation effect and brings back South's growth to North's level at the steady-state.

To summarize Propositions 3 and 4, the effect of an export subsidy by the developing country largely depends on the specialization pattern at the equilibrium. The export subsidy has a growth effect only if South is a small country in the sense that it is completely specialized while North is not. In the case where both countries are specialized, the export subsidy does not have any impact on the long-run growth rate but has a positive level effect. In both cases, the outcome of the export subsidy is different from that in Lucas (1988) and 
Young (1991), where subsidizing the good with the most (least) learning externalities always has a positive (negative) growth impact.

We end this section with two last comments. First, it is important to recall that we are conducting a steady-state analysis. Hence, a trade policy that may be growth maximizing in the long-run is not necessarily welfare enhancing. Second, the set of policies we have analyzed in this section is very limited. We are not making any claim that export subsidies are the optimal policy instrument, even in the reduced sense of being growth maximizing. In particular, one can show that in some cases a small production subsidy will have a larger impact on the long-run growth rate than an export subsidy of the same size ${ }^{16}$.

\section{Conclusion}

In this paper, we constructed a simple two-country model that is consistent with basic stylized facts about growth and trade patterns. We have shown that the conventional wisdom according to which exporting goods with limited learning potential and importing high learning goods is growth-impairing fails to hold when the imported good is a capital good. We contend that this result reconciles open economy endogenous growth models with the empirical evidence on trade and growth and, especially, with the growth experience of the outward-oriented East-Asian NIE's of the last few decades. The main lesson of the paper is that having access to cheap imported capital goods may be sufficiently important for a developing country as to dominate any other negative impact of trade on growth.

\footnotetext{
${ }^{16}$ Proof available upon request.
} 


\section{Bibliography}

Amsden, Alice (1986) “The Direction of Trade - Past and Present - and the Learning Effects of Exports to Different Directions" Journal of Development Economics, vol. 23, pp. 249274.

Backus, David, Patrick Kehoe and Timothy Kehoe (1992) "In Search of Scale Effects in Trade and Growth", Journal of Economic Theory, vol 58, pp.377-409

Balassa, Bela (1980) "Structural Change in Trade in Manufactured Goods between Industrial and Developing Countries", World Bank Staff Working Paper No. 396

Edwards, Sebastian (1998), "Openness, Productivity and Growth: What Do We Really Know?" Economic Journal, vol. 108, no. 447, pp. 383-398.

Egan, Lou Mary and Ashoka Mody (1992) "Buyer-Seller Links in Export Development." World Development, vol. 20, no. 3, pp.321-334.

Frankel, Jeffrey A., David Romer and Teresa Cyrus (1996) "Trade and Growth in East Asian Countries: Cause and Effect?" NBER Working Paper no. 5732.

GATT (1990) "International Trade 89-90 - Volume II"

Grossman, Gene M., and Elhanan Helpman (1991). Innovation and Growth. Cambridge: MIT press.

Harrison, Ann (1996) "Openness and Growth: a Time-Series, Cross-Country Analysis for Developing Countries", Journal of Development Economics, vol.48, pp. 419-447.

Jones, Charles (1994), "Economic Growth and the Relative Price of Capital", Journal of Monetary Economics, vol. 34, pp.359-382

Jones, Charles (1995), “Time Series Tests of Endogenous Growth Models”, Quaterly Journal of Economics, pp. 495-525. 
Jones, Charles (1997), "On the Evolution of the World Income Distribution", Journal of Economic Perspectives, pp. 19-36.

Jovanovic, Boyan (1995). “ Learning and Growth.” NBER working paper series no. 5383. Cambridge: NBER.

Keesing, Donald B. and Sanjaya Lall (1992) "Marketing Manufactured Exports from Developing Countries: Learning Sequences and Public Support” in Helleiner, Gerald K. (ed) Trade Policy, Industrialization, and Development : New Perspectives. New York: Oxford University Press.

Krugman, Paul (1979) "A Model of Innovation, Technology Transfer, and the World Distribution of Income" Journal of Political Economy, vol. 87, no. 2, pp. 253-266.

Lall, Sanjaya (1985) “Trade in Technology by a Slowly Industrializing Country: India” in Nathan Rosenberg and Claudio Frischtak (eds) International Technology Transfer: Concepts, Measures, and Comparisons. New York: Praeger.

Levine, Ross and David Renelt (1992) "A Sensitivity Analysis of Cross-Country Growth Regressions", American Economic Review, vol 82, no. 4, pp. 942-963.

Lucas, Robert E. Jr. (1988) "On the Mechanics of Economic Development.” Journal of Monetary Economics, vol. 22, July, pp.3-42.

Parente, Stephen L. and Edward C. Prescott (1993) "Changes in the Wealth of Nations." Federal Reserve Bank of Minneapolis Quarterly Review. Spring, pp. 3-16.

Rivera-Batiz, Luis A. and Paul Romer (1991a) "Economic Integration and Endogenous Growth." Quarterly Journal of Economics, vol. 106, May, pp.531-556.

Rivera-Batiz, Luis A. and Paul Romer (1991b) "International Trade with Endogenous Technological Change", European Economic Review, vol. 35, pp. 971-1004.

Stokey, Nancy L. (1988) “ Learning by Doing and the Introduction of New Goods", Journal of Political Economy, vol.96, pp. 701-717 
Stokey, Nancy L. (1991) “ Human Capital, Product Quality, and Growth.” Quarterly Journal of Economics, vol. 106, May, pp.587-616.

Vernon, R. (1966) "International Investment and International Trade in the Product Cycle." Quarterly Journal of Economics, vol. 80, pp. 190-207.

Young, Alwyn (1991) “Learning by Doing and the Dynamic Effects of International Trade." Quarterly Journal of Economics, vol. 106, May, pp.369-405. 


\section{Appendix A}

\section{Proof of Proposition 1:}

In what follows, the capital good is taken as the numeraire good. At time t, goods t, $\mathrm{k}$ and $\mathrm{t}-$ 1 are produced in the North under autarky. With perfectly competitive factor markets, factor rewards are equal to their marginal products:

$$
\begin{aligned}
& \mathrm{w}_{\mathrm{t}}^{\mathrm{N}}=\mathrm{P}_{\mathrm{t}, \mathrm{t}}^{\mathrm{N}} \alpha\left(\phi^{\mathrm{t}}\right)^{\alpha}\left(\frac{\mathrm{K}_{\mathrm{t}, \mathrm{t}}^{\mathrm{N}}}{\mathrm{H}_{\mathrm{t}, \mathrm{t}}^{\mathrm{N}}}\right)^{1-\alpha}=\alpha\left(\phi^{\mathrm{t}}\right)^{\alpha}\left(\frac{\mathrm{K}_{\mathrm{k}, \mathrm{t}}^{\mathrm{N}}}{\mathrm{H}_{\mathrm{k}, \mathrm{t}}^{\mathrm{N}}}\right)^{1-\alpha}=\mathrm{P}_{\mathrm{t}-1, \mathrm{t}}^{\mathrm{N}} \alpha\left(\phi^{\mathrm{t}-1}\right)^{\alpha}\left(\frac{\mathrm{K}_{\mathrm{t}-1, \mathrm{t}}^{\mathrm{N}}}{\mathrm{H}_{\mathrm{t}-1, \mathrm{t}}^{\mathrm{N}}}\right)^{1-\alpha} \\
& \mathrm{r}_{\mathrm{t}}^{\mathrm{N}}=\mathrm{P}_{\mathrm{t}, \mathrm{t}}^{\mathrm{N}}(1-\alpha)\left(\phi^{\mathrm{t}}\right)^{\alpha}\left(\frac{\mathrm{K}_{\mathrm{t}, \mathrm{t}}^{\mathrm{N}}}{\mathrm{H}_{\mathrm{t}, \mathrm{t}}^{\mathrm{N}}}\right)^{-\alpha}=(1-\alpha)\left(\phi^{\mathrm{t}}\right)^{\alpha}\left(\frac{\mathrm{K}_{\mathrm{k}, \mathrm{t}}^{\mathrm{N}}}{\mathrm{H}_{\mathrm{k}, \mathrm{t}}^{\mathrm{N}}}\right)^{-\alpha}=\mathrm{P}_{\mathrm{t}-1, \mathrm{t}}^{\mathrm{N}}(1-\alpha)\left(\phi^{\mathrm{t}-1}\right)^{\alpha}\left(\frac{\mathrm{K}_{\mathrm{t}-1, \mathrm{t}}^{\mathrm{N}}}{\mathrm{H}_{\mathrm{t}-1, \mathrm{t}}^{\mathrm{N}}}\right)^{-\alpha}
\end{aligned}
$$

$\mathrm{w}_{\mathrm{t}}$ and $\mathrm{r}_{\mathrm{t}}$ are the wage rate and rental rate, respectively. $\mathrm{P}_{\mathrm{i}, \mathrm{t}}$ denotes the prices of good $\mathrm{i}$ at time t.

From the agents' first order conditions, we get:

$$
\begin{aligned}
& \mathrm{P}_{\mathrm{t}-1, \mathrm{t}}^{\mathrm{N}} \mathrm{c}_{\mathrm{t}-1, \mathrm{t}}^{\mathrm{N}}=\frac{\varepsilon}{1+\beta} \mathrm{w}_{\mathrm{t}}^{\mathrm{N}} \mathrm{h}_{\mathrm{t}}^{\mathrm{N}} \quad ; \quad \mathrm{P}_{\mathrm{t}, \mathrm{t}}^{\mathrm{N}} \mathrm{c}_{\mathrm{t}, \mathrm{t}}^{\mathrm{N}}=\frac{1-\varepsilon}{1+\beta} \mathrm{w}_{\mathrm{t}}^{\mathrm{N}} \mathrm{h}_{\mathrm{t}}^{\mathrm{N}} \\
& \mathrm{P}_{t, t+1}^{\mathrm{N}} \mathrm{c}_{t, \mathrm{t}+1}^{\mathrm{N}}=\frac{\varepsilon \beta}{1+\beta} \mathrm{w}_{\mathrm{t}}^{\mathrm{N}} \mathrm{h}_{\mathrm{t}}^{\mathrm{N}} \frac{\mathrm{r}_{\mathrm{t}+1}^{\mathrm{N}}}{\mathrm{P}_{\mathrm{k}, \mathrm{t}}^{\mathrm{N}}} \quad ; \quad \mathrm{P}_{\mathrm{t}+1, \mathrm{t}+1}^{\mathrm{N}} \mathrm{c}_{\mathrm{t}+1, \mathrm{t}+1}^{\mathrm{N}}=\frac{(1-\varepsilon) \beta}{1+\beta} \mathrm{w}_{\mathrm{t}}^{\mathrm{N}} \mathrm{h}_{\mathrm{t}}^{\mathrm{N}} \frac{\mathrm{r}_{\mathrm{t}+1}^{\mathrm{N}}}{\mathrm{P}_{\mathrm{k}, \mathrm{t}}^{\mathrm{N}}} \\
& \mathrm{P}_{\mathrm{k}, \mathrm{t}}^{\mathrm{N}} \mathrm{s}_{\mathrm{t}}^{\mathrm{N}}=\frac{\beta}{1+\beta} \mathrm{w}_{\mathrm{t}}^{\mathrm{N}} \mathrm{h}_{\mathrm{t}}^{\mathrm{N}}
\end{aligned}
$$

Substituting the agents' f.o.c into the law of motion of capital and the good markets clearing conditions yields:

$$
\begin{aligned}
\mathrm{K}_{\mathrm{t}+1}^{\mathrm{N}} & =\frac{\beta \mathrm{w}_{\mathrm{t}}^{\mathrm{N}} \mathrm{H}_{\mathrm{t}}^{\mathrm{N}}}{(1+\beta)} \\
\mathrm{Y}_{\mathrm{t}-1, \mathrm{t}}^{\mathrm{N}} & =\frac{\varepsilon \mathrm{w}_{\mathrm{t}}^{\mathrm{N}} \mathrm{H}_{\mathrm{t}}^{\mathrm{N}}}{(1+\beta) \mathrm{P}_{\mathrm{t}-1, \mathrm{t}}^{\mathrm{N}}}+\frac{\varepsilon \mathrm{r}_{\mathrm{t}}^{\mathrm{N}} \mathrm{K}_{\mathrm{t}}^{\mathrm{N}}}{\mathrm{P}_{\mathrm{t}-1, \mathrm{t}}^{\mathrm{N}}}
\end{aligned}
$$




$$
\begin{aligned}
& Y_{t, t}^{N}=\frac{(1-\varepsilon) \mathrm{w}_{t}^{N} H_{t}^{N}}{(1+\beta) P_{t, t}^{N}}+\frac{(1-\varepsilon) r_{t}^{N} K_{t}^{N}}{P_{t, t}^{N}} \\
& Y_{k, t}^{N}=\frac{\beta w_{t}^{N} H_{t}^{N}}{(1+\beta)}
\end{aligned}
$$

Substituting equations (A1) and (A2) into equations (A8) and (A9), we get the fraction of human capital used in the production of, respectively, goods $\mathrm{t}$ and $\mathrm{k}$ :

$$
\begin{aligned}
& \frac{\mathrm{H}_{\mathrm{t}, \mathrm{t}}^{\mathrm{N}}}{\mathrm{H}_{\mathrm{t}}^{\mathrm{N}}}=\frac{(1-\varepsilon) \alpha}{1+\beta}+(1-\varepsilon)(1-\alpha) \\
& \frac{\mathrm{H}_{\mathrm{k}, \mathrm{t}}^{\mathrm{N}}}{\mathrm{H}_{\mathrm{t}}^{\mathrm{N}}}=\frac{\beta \alpha}{1+\beta}
\end{aligned}
$$

Since capital/labor ratios are the same across sectors, substituting (A1) into (A6) and dividing the resulting equation by $\mathrm{H}_{\mathrm{t}+1}^{\mathrm{N}}$ we get:

$$
\frac{\mathrm{K}_{\mathrm{t}+1}^{\mathrm{N}}}{\mathrm{H}_{\mathrm{t}+1}^{\mathrm{N}}}=\frac{\beta}{1+\beta} \alpha\left(\phi^{\mathrm{t}}\right)^{\alpha}\left(\frac{\mathrm{K}_{\mathrm{t}}^{\mathrm{N}}}{\mathrm{H}_{\mathrm{t}}^{\mathrm{N}}}\right)^{1-\alpha}\left(\frac{\mathrm{H}_{\mathrm{t}}^{\mathrm{N}}}{\mathrm{H}_{\mathrm{t}+1}^{\mathrm{N}}}\right)
$$

Along the steady state growth path, the capital per (effective) worker ratio is constant over time. Thus, we have:

$$
\begin{aligned}
& \frac{\mathrm{K}_{\mathrm{t}+1}^{\mathrm{N}}}{\phi^{\mathrm{t}+1} \mathrm{H}_{\mathrm{t}+1}^{\mathrm{N}}}=\frac{\mathrm{K}_{\mathrm{t}}^{\mathrm{N}}}{\phi^{\mathrm{t}} \mathrm{H}_{\mathrm{t}}^{\mathrm{N}}} \text {, and with } \mathrm{H}_{\mathrm{t}+1}^{\mathrm{N}}=\mathrm{H}_{\mathrm{t}}^{\mathrm{N}}\left(1+\mathrm{g}_{\mathrm{H}}^{\mathrm{N}}\right), \mathrm{A}(12) \text { yields: } \\
& \frac{\mathrm{K}_{\mathrm{t}+1}^{\mathrm{N}}}{\phi^{\mathrm{t}+1} \mathrm{H}_{\mathrm{t}+1}^{\mathrm{N}}}=\left(\frac{\beta}{1+\beta} \frac{\alpha}{\phi} \frac{1}{1+\mathrm{g}_{\mathrm{H}}^{\mathrm{N}}}\right)^{\frac{1}{\alpha}}
\end{aligned}
$$

The learning equation (4) can be rewritten as: 


$$
\frac{\mathrm{H}_{\mathrm{t}+1}^{\mathrm{N}}-\mathrm{H}_{\mathrm{t}}^{\mathrm{N}}}{\mathrm{H}_{\mathrm{t}}^{\mathrm{N}}}=\left[\mathrm{a}_{\mathrm{c}} \frac{\mathrm{H}_{\mathrm{t}, \mathrm{t}}^{\mathrm{N}}}{\mathrm{H}_{\mathrm{t}}^{\mathrm{N}}}\left(\frac{\mathrm{K}_{\mathrm{t}, \mathrm{t}}^{\mathrm{N}}}{\phi^{\mathrm{t}} \mathrm{H}_{\mathrm{t}, \mathrm{t}}^{\mathrm{N}}}\right)^{1-\alpha}+\mathrm{a}_{\mathrm{k}} \frac{\mathrm{H}_{\mathrm{k}, \mathrm{t}}^{\mathrm{N}}}{\mathrm{H}_{\mathrm{t}}^{\mathrm{N}}}\left(\frac{\mathrm{K}_{\mathrm{k}, \mathrm{t}}^{\mathrm{N}}}{\phi^{\mathrm{t}} \mathrm{H}_{\mathrm{k}, \mathrm{t}}^{\mathrm{N}}}\right)^{1-\alpha}\right]^{\delta}
$$

Substituting (A10), (A11) and (A13) into (A14), we get:

$$
\left(\mathrm{g}_{\mathrm{H}}^{\mathrm{A}}\right)^{\frac{1}{\delta}}\left(1+\mathrm{g}_{\mathrm{H}}^{\mathrm{A}}\right)^{\frac{1-\alpha}{\alpha}}=\left(\frac{\alpha}{\phi} \frac{\beta}{1+\beta}\right)^{\frac{(1-\alpha)}{\alpha}}\left\{\mathrm{a}_{\mathrm{c}}\left[\frac{(1-\varepsilon) \alpha}{1+\beta}+(1-\varepsilon)(1-\alpha)\right]+\mathrm{a}_{\mathrm{k}} \frac{\alpha \beta}{1+\beta}\right\}
$$

Note that the LHS is a monotonic function of $\mathrm{g}_{\mathrm{H}}$, is equal to zero when the growth rate is equal to zero and goes to infinity when the growth rate goes to infinity. Since the RHS is a positive constant, $\mathrm{g}_{\mathrm{H}}$ is uniquely defined by (A15). As South is identical to North except for the one period lag in the arrival of new designs, it follows that the autarky growth rate is the same as North. QED.

\section{Proof of Proposition 2:}

\section{Case I: Free trade equilibrium with complete specialization in the South only}

$\underline{\text { South }}$

Substituting agents' f.o.c into the goods market clearing conditions we obtain as before:

$$
\begin{aligned}
& \frac{\mathrm{H}_{\mathrm{t}-2, \mathrm{t}}^{\mathrm{S}}}{\mathrm{H}_{\mathrm{t}}^{\mathrm{S}}}=\frac{\varepsilon \alpha}{1+\beta}+\varepsilon(1-\alpha) \\
& \frac{\mathrm{H}_{\mathrm{t}-1, \mathrm{t}}^{\mathrm{S}}}{\mathrm{H}_{\mathrm{t}}^{\mathrm{S}}}=1-\left[\frac{\varepsilon \alpha}{1+\beta}+\varepsilon(1-\alpha)\right]
\end{aligned}
$$

Equating the savings of agents to the next period capital stock yields:

$$
\mathrm{K}_{\mathrm{t}+1}^{\mathrm{S}}=\frac{\beta \mathrm{w}_{\mathrm{t}}^{\mathrm{S}} \mathrm{H}_{\mathrm{t}}^{\mathrm{S}}}{(1+\beta)}
$$

Substituting $\mathrm{w}_{\mathrm{t}}^{\mathrm{S}}=\mathrm{P}_{\mathrm{t}-1, \mathrm{t}}^{\mathrm{N}} \alpha\left(\phi^{\mathrm{t}-1}\right)^{\alpha}\left(\frac{\mathrm{K}_{\mathrm{t}-1, \mathrm{t}}^{\mathrm{S}}}{\mathrm{H}_{\mathrm{t}-1, \mathrm{t}}^{\mathrm{S}}}\right)^{1-\alpha}$ into (A18) and dividing the resulting equation by 
$\mathrm{H}_{\mathrm{t}+1}^{\mathrm{S}}$ gives:

$$
\frac{\mathrm{K}_{\mathrm{t}+1}^{\mathrm{S}}}{\phi^{\mathrm{t}} \mathrm{H}_{\mathrm{t}+1}^{\mathrm{S}}}=\left(\mathrm{P}_{\mathrm{t}-1, \mathrm{t}}^{\mathrm{N}} \frac{\beta}{1+\beta} \frac{\alpha}{\phi} \frac{1}{1+\mathrm{g}_{\mathrm{H}}^{\mathrm{S}, \mathrm{T}}}\right)^{\frac{1}{\alpha}}
$$

Substituting (A17) and (A19) into the learning equation (8) of the South, we get:

$$
\left(\mathrm{g}_{\mathrm{H}}^{\mathrm{S}, \mathrm{T}}\right)^{\frac{1}{\delta}}=\mathrm{a}_{\mathrm{c}}\left[1-\frac{\varepsilon \alpha}{1+\beta}-\varepsilon(1-\alpha)\right]\left(\mathrm{P}_{\mathrm{t}-1, \mathrm{t}}^{\mathrm{N}} \frac{\alpha}{\phi} \frac{\beta}{1+\beta} \frac{1}{1+\mathrm{g}_{\mathrm{H}}^{\mathrm{S}, \mathrm{T}}}\right)^{\frac{1-\alpha}{\alpha}}
$$

or:

$$
\left(\mathrm{g}_{\mathrm{H}}^{\mathrm{S}, \mathrm{T}}\right)^{\frac{1}{\delta}}\left(1+\mathrm{g}_{\mathrm{H}}^{\mathrm{S}, \mathrm{T}}\right)^{\frac{(1-\alpha)}{\alpha}}=\mathrm{a}_{\mathrm{c}}\left[1-\varepsilon\left(1-\frac{\alpha \beta}{1+\beta}\right)\right]\left(\frac{\alpha}{\phi} \frac{\beta}{1+\beta}\right)^{\frac{(1-\alpha)}{\alpha}} \phi^{1-\alpha}
$$

\section{North}

Substituting (A1) into the capital accumulation equation (A6) and dividing the resulting equation by $\mathrm{H}_{\mathrm{t}+1}^{\mathrm{N}}$ yields:

$$
\frac{\mathrm{K}_{\mathrm{t}+1}^{\mathrm{N}}}{\phi^{\mathrm{t}+1} \mathrm{H}_{\mathrm{t}+1}^{\mathrm{N}}}=\left(\frac{\beta}{1+\beta} \frac{\alpha}{\phi} \frac{1}{1+\mathrm{g}_{\mathrm{H}}^{\mathrm{N}, \mathrm{T}}}\right)^{\frac{1}{\alpha}}
$$

As in the autarky case we obtain from the goods market clearing conditions:

$$
\begin{aligned}
& \frac{\mathrm{H}_{\mathrm{t}, \mathrm{t}}^{\mathrm{N}}}{\mathrm{H}_{\mathrm{t}}^{\mathrm{N}}}=\frac{(1-\varepsilon) \alpha}{1+\beta}+(1-\varepsilon)(1-\alpha) \\
& \mathrm{Y}_{\mathrm{k}, \mathrm{t}}^{\mathrm{N}}=\frac{\beta \mathrm{w}_{\mathrm{t}}^{\mathrm{N}} \mathrm{H}_{\mathrm{t}}^{\mathrm{N}}}{(1+\beta)}+\frac{\beta \mathrm{w}_{\mathrm{t}}^{\mathrm{S}} \mathrm{H}_{\mathrm{t}}^{\mathrm{S}}}{(1+\beta)} \\
& \Leftrightarrow\left(\phi^{\mathrm{t}}\right)^{\alpha}\left(\frac{\mathrm{K}_{\mathrm{k}, \mathrm{t}}^{\mathrm{N}}}{\mathrm{H}_{\mathrm{k}, \mathrm{t}}^{\mathrm{N}}}\right)^{1-\alpha} \mathrm{H}_{\mathrm{k}, \mathrm{t}}^{\mathrm{N}}=\frac{\beta}{1+\beta} \alpha\left(\phi^{\mathrm{t}}\right)^{\alpha}\left(\frac{\mathrm{K}_{\mathrm{k}, \mathrm{t}}^{\mathrm{N}}}{\mathrm{H}_{\mathrm{k}, \mathrm{t}}^{\mathrm{N}}}\right)^{1-\alpha} \mathrm{H}_{\mathrm{t}}^{\mathrm{N}}+\frac{\beta}{1+\beta} \mathrm{P}_{\mathrm{t}-1, \mathrm{t}}^{\mathrm{N}} \alpha\left(\phi^{\mathrm{t}-1}\right)^{\alpha}\left(\frac{\mathrm{K}_{\mathrm{t}-1, \mathrm{t}}^{\mathrm{S}}}{\mathrm{H}_{\mathrm{t}-1, \mathrm{t}}^{\mathrm{S}}}\right)^{1-\alpha} \mathrm{H}_{\mathrm{t}}^{\mathrm{S}} \\
& \Leftrightarrow \frac{\mathrm{H}_{\mathrm{k}, \mathrm{t}}^{\mathrm{N}}}{\mathrm{H}_{\mathrm{t}}^{\mathrm{N}}}=\frac{\alpha \beta}{1+\beta}\left(1+\frac{\mathrm{H}_{\mathrm{t}}^{\mathrm{S}}}{\mathrm{H}_{\mathrm{t}}^{\mathrm{N}}}\right)
\end{aligned}
$$

Substituting (A22), (A23) and (A24) into the learning equation (4), we have: 
$\left(\mathrm{g}_{\mathrm{H}}^{\mathrm{N}, \mathrm{T}}\right)^{\frac{1}{\delta}}\left(1+\mathrm{g}_{\mathrm{H}}^{\mathrm{N}, \mathrm{T}}\right)^{\frac{1-\alpha}{\alpha}}=\left(\frac{\alpha \beta}{\phi(1+\beta)}\right)^{\frac{1-\alpha}{\alpha}}\left\{\mathrm{a}_{\mathrm{c}}\left[\frac{(1-\varepsilon) \alpha}{1+\beta}+(1-\varepsilon)(1-\alpha)\right]+\mathrm{a}_{\mathrm{k}} \frac{\alpha \beta}{1+\beta}\left(1+\frac{\mathrm{H}_{\mathrm{t}}^{\mathrm{S}}}{\mathrm{H}_{\mathrm{t}}^{\mathrm{N}}}\right)\right\}(\mathrm{A} 25)$

We note that the LHS of (A25) is an increasing function of $\mathrm{g}_{\mathrm{H}}$. Comparing (A25) and (A15), we see that the RHS of (A25) is strictly larger than that of (A15). Therefore, if a balanced growth path exists, growth is strictly higher under free trade.

We equate the growth rate of the two countries to obtain the relative size of the economies along the balanced growth path:

$$
\frac{\mathrm{H}_{\mathrm{t}}^{\mathrm{s}}}{\mathrm{H}_{\mathrm{t}}^{\mathrm{N}}}=\frac{\mathrm{a}_{\mathrm{c}}\left[1-\varepsilon\left(1-\frac{\alpha \beta}{1+\beta}\right)\right]\left(\phi^{(1-\alpha)}-1\right)+\left(\mathrm{a}_{\mathrm{c}}-\mathrm{a}_{\mathrm{k}}\right) \frac{\alpha \beta}{1+\beta}}{\mathrm{a}_{\mathrm{k}} \frac{\alpha \beta}{1+\beta}}
$$

We note that a balanced growth path with only South specializing completely exists iff:

i) $\frac{\mathrm{H}_{\mathrm{t}}^{\mathrm{S}}}{\mathrm{H}_{\mathrm{t}}^{\mathrm{N}}}>0 \Leftrightarrow \frac{\mathrm{a}_{\mathrm{k}}}{\mathrm{a}_{\mathrm{c}}}<1+\frac{\left[1-\varepsilon\left(1-\frac{\alpha \beta}{1+\beta}\right)\right]\left(\phi^{(1-\alpha)}-1\right)}{\frac{\alpha \beta}{1+\beta}}$

and:

ii) $\frac{\mathrm{H}_{\mathrm{t}-1, \mathrm{t}}^{\mathrm{N}}}{\mathrm{H}_{\mathrm{t}}^{\mathrm{N}}}>0 \Leftrightarrow 1-\frac{(1-\varepsilon) \alpha}{1+\beta}-(1-\varepsilon)(1-\alpha)-\frac{\alpha \beta}{1+\beta}\left(1+\frac{\mathrm{H}_{\mathrm{t}}^{\mathrm{S}}}{\mathrm{H}_{\mathrm{t}}^{\mathrm{N}}}\right)>0$

$\Leftrightarrow \frac{a_{k}}{a_{c}}>1+\frac{\left[1-\varepsilon\left(1-\frac{\alpha \beta}{1+\beta}\right)\right] \phi^{1-\alpha}-1}{\frac{\alpha \beta}{1+\beta}+\left(1-\frac{\alpha \beta}{1+\beta}\right) \varepsilon}$

QED

\section{Case II: Free trade equilibrium with both North and South completely specialized.}

i) As in the autarky case, we obtain from the goods market clearing conditions: 


$$
\frac{\mathrm{H}_{\mathrm{t}, \mathrm{t}}^{\mathrm{N}}}{\mathrm{H}_{\mathrm{t}}^{\mathrm{N}}}=\frac{(1-\varepsilon) \alpha}{1+\beta}+(1-\varepsilon)(1-\alpha)
$$

Since North is completely specialized, we get:

$$
\frac{\mathrm{H}_{\mathrm{k}, \mathrm{t}}^{\mathrm{N}}}{\mathrm{H}_{\mathrm{t}}^{\mathrm{N}}}=1-\frac{(1-\varepsilon) \alpha}{1+\beta}-(1-\varepsilon)(1-\alpha)=\frac{\alpha \beta}{1+\beta}+\varepsilon\left(1-\frac{\alpha \beta}{1+\beta}\right)
$$

Substituting (A22), (A29) and (A30) into the learning equation (4) for the North, we get:

$$
\left(\mathrm{g}_{\mathrm{H}}^{\mathrm{N}, \mathrm{T}}\right)^{\frac{1}{\delta}}\left(1+\mathrm{g}_{\mathrm{H}}^{\mathrm{N}, \mathrm{T}}\right)^{\frac{1-\alpha}{\alpha}}=\left(\frac{\alpha \beta}{\phi(1+\beta)}\right)^{\frac{1-\alpha}{\alpha}}\left\{\mathrm{a}_{\mathrm{c}}\left[\frac{(1-\varepsilon) \alpha}{1+\beta}+(1-\varepsilon)(1-\alpha)\right]+\mathrm{a}_{\mathrm{k}}\left[\frac{\alpha \beta}{1+\beta}+\varepsilon\left(1-\frac{\alpha \beta}{1+\beta}\right)\right]\right\}(\mathrm{A} 31)
$$

Note that the RHS of (A31) is strictly greater than (A15) and hence the growth rate of human capital is strictly higher under free trade.

Denoting the terms of trade for the traded consumption good by $\mathrm{P}_{\mathrm{t}-1, \mathrm{t}}^{\mathrm{W}}$, we get from (A20):

$$
\left(\mathrm{g}_{\mathrm{H}}^{\mathrm{S}, \mathrm{T}}\right)^{\frac{1}{\delta}}\left(1+\mathrm{g}_{\mathrm{H}}^{\mathrm{S}, \mathrm{T}}\right)^{\frac{(1-\alpha)}{\alpha}}=\mathrm{a}_{\mathrm{c}}\left[(1-\varepsilon)+\frac{\varepsilon \alpha \beta}{1+\beta}\right]\left(\mathrm{P}_{\mathrm{t}-1, \mathrm{t}}^{\mathrm{W}} \frac{\alpha}{\phi} \frac{\beta}{1+\beta}\right)^{\frac{(1-\alpha)}{\alpha}}
$$

We next find the terms of trade such that the two economies grow at the same rate. Equating (A31) and (A32), we get:

$$
\left(\mathrm{P}_{\mathrm{t}-1, \mathrm{t}}^{\mathrm{w}}\right)^{1-\alpha} \frac{\mathrm{a}_{\mathrm{c}}\left[\frac{(1-\varepsilon) \alpha}{1+\beta}+(1-\varepsilon)(1-\alpha)\right]+\mathrm{a}_{\mathrm{k}}\left[\frac{\alpha \beta}{1+\beta}+\varepsilon\left(1-\frac{\alpha \beta}{1+\beta}\right)\right]}{\mathrm{a}_{\mathrm{c}}\left[(1-\varepsilon)+\frac{\varepsilon \alpha \beta}{1+\beta}\right]}
$$

Note that the terms of trade must lie between the autarky relative prices of the two economies. This implies that for such a balanced growth path to exist we need:

$1 \leq \mathrm{P}_{\mathrm{t}-1, \mathrm{t}}^{\mathrm{W}} \leq \phi^{\alpha}$ 
or:

$\frac{1}{1+\left(\frac{1+\beta}{\alpha \beta}-1\right) \varepsilon} \leq \frac{a_{k}}{a_{c}} \leq 1+\frac{\left[1-\varepsilon\left(1-\frac{\alpha \beta}{1+\beta}\right)\right] \phi^{1-\alpha}-1}{\frac{\alpha \beta}{1+\beta}+\left(1-\frac{\alpha \beta}{1+\beta}\right) \varepsilon}$

Note that the LHS inequality is automatically satisfied by Assumption 4.

Finally, we solve for the relative size of North versus South at the equilibrium. From the market clearing condition for the capital good in North we have:

$$
\begin{aligned}
& \left(\phi^{\mathrm{t}}\right)\left(\frac{\mathrm{K}_{\mathrm{k}, \mathrm{t}}^{\mathrm{N}}}{\phi^{\mathrm{t}} \mathrm{H}_{\mathrm{k}, \mathrm{t}}^{\mathrm{N}}}\right)^{1-\alpha} \mathrm{H}_{\mathrm{k}, \mathrm{t}}^{\mathrm{N}}=\frac{\beta}{1+\beta} \alpha \phi^{\mathrm{t}}\left(\frac{\mathrm{K}_{\mathrm{k}, \mathrm{t}}^{\mathrm{N}}}{\phi^{\mathrm{t}} \mathrm{H}_{\mathrm{k}, \mathrm{t}}^{\mathrm{N}}}\right)^{1-\alpha} \mathrm{H}_{\mathrm{t}}^{\mathrm{N}}+\frac{\beta}{1+\beta} \mathrm{P}_{\mathrm{t}-1, \mathrm{t}}^{\mathrm{W}} \alpha \phi^{\mathrm{t}-1}\left(\frac{\mathrm{K}_{\mathrm{t}-1, \mathrm{t}}^{\mathrm{N}}}{\phi^{\mathrm{t}-1} \mathrm{H}_{\mathrm{t}-1, \mathrm{t}}^{\mathrm{N}}}\right)^{1-\alpha} \mathrm{H}_{\mathrm{t}}^{\mathrm{S}} \\
& \Leftrightarrow \frac{\mathrm{H}_{\mathrm{k}, \mathrm{t}}^{\mathrm{N}}}{\mathrm{H}_{\mathrm{t}}^{\mathrm{N}}}=\frac{\alpha \beta}{1+\beta}\left(1+\frac{\mathrm{H}_{\mathrm{t}}^{\mathrm{S}}}{\mathrm{H}_{\mathrm{t}}^{\mathrm{N}}} \frac{\mathrm{P}_{\mathrm{t}-1, \mathrm{t}}^{\mathrm{W}}}{\phi}\right)
\end{aligned}
$$

Substituting (A30) into (A35) we have:

$$
\frac{\mathrm{H}_{\mathrm{t}}^{\mathrm{s}}}{\mathrm{H}_{\mathrm{t}}^{\mathrm{N}}}=\frac{\phi \varepsilon\left(1-\frac{\alpha \beta}{1+\beta}\right)}{\frac{\alpha \beta}{1+\beta} \mathrm{P}_{\mathrm{t}-1, \mathrm{t}}^{\mathrm{w}} \frac{1}{\alpha}}
$$

Substituting (A33) into (A36), we get:

$$
\frac{\mathrm{H}_{\mathrm{t}}^{\mathrm{s}}}{\mathrm{H}_{\mathrm{t}}^{\mathrm{N}}}=\frac{\phi \varepsilon\left(1-\frac{\alpha \beta}{1+\beta}\right)\left\{\mathrm{a}_{\mathrm{c}}\left[1-\varepsilon\left(1-\frac{\alpha \beta}{1+\beta}\right)\right]\right\}^{\frac{1}{1-\alpha}}}{\frac{\alpha \beta}{1+\beta}\left\{\mathrm{a}_{\mathrm{c}}\left[\frac{(1-\varepsilon) \alpha}{1+\beta}+(1-\varepsilon)(1-\alpha)\right]+\mathrm{a}_{\mathrm{k}}\left[\frac{\alpha \beta}{1+\beta}+\varepsilon\left(1-\frac{\alpha \beta}{1+\beta}\right)\right]\right\}^{\frac{1}{1-\alpha}}}
$$




\section{Appendix B}

Proof of Proposition 3

Note first that:

$\mathrm{P}_{\mathrm{t}-1, \mathrm{t}}^{\mathrm{N}} \mathrm{I}_{\mathrm{t}}^{\mathrm{N}}=\mathrm{P}_{\mathrm{t}-1, \mathrm{t}}^{\mathrm{S}} \mathrm{E}_{\mathrm{t}}^{\mathrm{S}}(1-\mathrm{s}) \Rightarrow \mathrm{P}_{\mathrm{t}-1, \mathrm{t}}^{\mathrm{S}}=\frac{\mathrm{P}_{\mathrm{t}-1, \mathrm{t}}^{\mathrm{N}}}{1-\mathrm{s}}$

where $\mathrm{P}_{\mathrm{t}-1, \mathrm{t}}^{\mathrm{N}}$ is the price faced by consumers in North and $\mathrm{P}_{\mathrm{t}-1, \mathrm{t}}^{\mathrm{S}}$ is the price faced by consumers in South which also equals to the unit cost of production under perfect competition.

Goods market clearing conditions:

$$
\begin{aligned}
& \mathrm{Y}_{\mathrm{t}-1, \mathrm{t}}^{\mathrm{S}}=\frac{(1-\varepsilon) \mathrm{w}_{\mathrm{t}}^{\mathrm{S}} \mathrm{H}_{\mathrm{t}}^{\mathrm{S}}(1-\mathrm{d})}{(1+\beta) \mathrm{P}_{\mathrm{t}-1, \mathrm{t}}^{\mathrm{S}}}+\frac{(1-\varepsilon) \mathrm{r}_{\mathrm{t}}^{\mathrm{S}} \mathrm{K}_{\mathrm{t}}^{\mathrm{S}}(1-\mathrm{d})}{\mathrm{P}_{\mathrm{t}-1, \mathrm{t}}^{\mathrm{S}}}+\mathrm{E}_{\mathrm{t}-1, \mathrm{t}}^{\mathrm{S}} \\
& \mathrm{I}_{\mathrm{k}, \mathrm{t}}^{\mathrm{S}}=\frac{\beta \mathrm{w}_{\mathrm{t}}^{\mathrm{S}} \mathrm{H}_{\mathrm{t}}^{\mathrm{S}}(1-\mathrm{d})}{(1+\beta)} \\
& \mathrm{Y}_{\mathrm{t}-2, \mathrm{t}}^{\mathrm{S}}=\frac{\varepsilon \mathrm{w}_{\mathrm{t}}^{\mathrm{S}} \mathrm{H}_{\mathrm{t}}^{\mathrm{S}}(1-\mathrm{d})}{(1+\beta) \mathrm{P}_{\mathrm{t}-2, \mathrm{t}}^{\mathrm{S}}}+\frac{\varepsilon \mathrm{r}_{\mathrm{t}}^{\mathrm{S}} \mathrm{K}_{\mathrm{t}}^{\mathrm{S}}(1-\mathrm{d})}{\mathrm{P}_{\mathrm{t}-2, \mathrm{t}}^{\mathrm{S}}}
\end{aligned}
$$

As in the proofs of Propositions 1 and 2, we get from the goods market clearing conditions:

$$
\begin{aligned}
& \frac{\mathrm{H}_{\mathrm{t}-2, \mathrm{t}}^{\mathrm{s}}}{\mathrm{H}_{\mathrm{t}}^{\mathrm{S}}}=\frac{\varepsilon \alpha(1-\mathrm{d})}{1+\beta}+\varepsilon(1-\alpha)(1-\mathrm{d}) \\
& \frac{\mathrm{H}_{\mathrm{t}-1, \mathrm{t}}^{\mathrm{S}}}{\mathrm{H}_{\mathrm{t}}^{\mathrm{s}}}=1-\frac{\varepsilon \alpha(1-\mathrm{d})}{1+\beta}-\varepsilon(1-\alpha)(1-\mathrm{d})
\end{aligned}
$$

Equating agents' savings to next period capital stock and dividing both sides of the equation by $\mathrm{H}_{\mathrm{t}+1}^{\mathrm{S}}$ :

$$
\frac{\mathrm{K}_{\mathrm{t}+1}^{\mathrm{S}}}{\mathrm{H}_{\mathrm{t}+1}^{\mathrm{s}}}=\frac{\beta \mathrm{w}_{\mathrm{t}}^{\mathrm{S}} \mathrm{H}_{\mathrm{t}}^{\mathrm{S}}(1-\mathrm{d})}{(1+\beta) \mathrm{H}_{\mathrm{t}+1}^{\mathrm{S}}}
$$


Substituting $\mathrm{w}_{\mathrm{t}}^{\mathrm{S}}=\mathrm{P}_{\mathrm{t}-1, \mathrm{t}}^{\mathrm{S}} \alpha\left(\phi^{\mathrm{t}-1}\right)^{\alpha}\left(\frac{\mathrm{K}_{\mathrm{t}-1, \mathrm{t}}^{\mathrm{s}}}{\mathrm{H}_{\mathrm{t}-1, \mathrm{t}}^{\mathrm{s}}}\right)^{1-\alpha}$ we get:

$$
\frac{\mathrm{K}_{\mathrm{t}+1}^{\mathrm{S}}}{\mathrm{H}_{\mathrm{t}+1}^{\mathrm{S}}}=\frac{\beta \alpha \mathrm{P}_{\mathrm{t}-1, \mathrm{t}}^{\mathrm{S}}\left(\phi^{\mathrm{t}-1}\right)^{\alpha}\left(\frac{\mathrm{K}_{\mathrm{t}-1, \mathrm{t}}^{\mathrm{S}}}{\mathrm{H}_{\mathrm{t}-1, \mathrm{t}}^{\mathrm{s}}}\right)^{1-\alpha}(1-\mathrm{d})}{(1+\beta)\left(1+\mathrm{g}_{\mathrm{H}}\right)}
$$

Since the capital-labor ratios are equalized across sectors, and by definition of a balanced growth path, (B7) is equivalent to:

$$
\frac{\mathrm{K}_{\mathrm{t}+1}^{\mathrm{s}}}{\phi^{\mathrm{t}} \mathrm{H}_{\mathrm{t}+1}^{\mathrm{s}}}=\left(\frac{\alpha \beta(1-\mathrm{d})}{\phi^{1-\alpha}(1+\beta)(1-\mathrm{s})\left(1+\mathrm{g}_{\mathrm{H}}\right)}\right)^{\frac{1}{\alpha}}
$$

By the definition of $d$, we have:

$$
\begin{aligned}
& \mathrm{d}\left(\mathrm{r}_{\mathrm{t}}^{\mathrm{S}} \mathrm{K}_{\mathrm{t}}^{\mathrm{S}}+\mathrm{w}_{\mathrm{t}}^{\mathrm{S}} \mathrm{H}_{\mathrm{t}}^{\mathrm{S}}\right)=\mathrm{sP}_{\mathrm{t}-1, \mathrm{t}}^{\mathrm{S}} \mathrm{E}_{\mathrm{t}-1, \mathrm{t}}^{\mathrm{s}}=\frac{\mathrm{s}}{1-\mathrm{s}} \mathrm{I}_{\mathrm{k}, \mathrm{t}}^{\mathrm{s}} \\
& \Leftrightarrow \mathrm{d}\left(\frac{\mathrm{r}_{\mathrm{t}}^{\mathrm{S}} \mathrm{K}_{\mathrm{t}}^{\mathrm{S}}}{\mathrm{w}_{\mathrm{t}}^{\mathrm{S}} \mathrm{H}_{\mathrm{t}}^{\mathrm{s}}}+1\right)=\frac{\mathrm{s} \beta(1-\mathrm{d})}{(1-\mathrm{s})(1+\beta)} \\
& \Leftrightarrow 1-\mathrm{d}=\frac{(1-\mathrm{s})(1+\beta)}{\alpha \mathrm{s} \beta+(1-\mathrm{s})(1+\beta)}
\end{aligned}
$$

Substituting (B5) and (B8) into the learning equation (8), we get:

$$
\left(\mathrm{g}_{\mathrm{H}}^{\mathrm{S}}\right)^{\frac{1}{\delta}}=\mathrm{a}_{\mathrm{c}}\left(\frac{\mathrm{K}_{\mathrm{t}-1, \mathrm{t}}^{\mathrm{s}}}{\phi^{\mathrm{t}-1} \mathrm{H}_{\mathrm{t}-1, \mathrm{t}}^{\mathrm{S}}}\right)^{1-\alpha} \frac{\mathrm{H}_{\mathrm{t}-1, \mathrm{t}}^{\mathrm{s}}}{\mathrm{H}_{\mathrm{t}}^{\mathrm{s}}}=\mathrm{a}_{\mathrm{c}}\left(\frac{\alpha \beta(1-\mathrm{d})}{\phi^{1-\alpha}(1+\beta)(1-\mathrm{s})\left(1+\mathrm{g}_{\mathrm{H}}\right)}\right)^{\frac{1-\alpha}{\alpha}}\left[1-\varepsilon(1-\mathrm{d})\left(1-\frac{\alpha \beta}{1+\beta}\right)\right]
$$

or:

$$
\left(\mathrm{g}_{\mathrm{H}}^{\mathrm{s}}\right)^{\frac{1}{\delta}}\left(1+\mathrm{g}_{\mathrm{H}}^{\mathrm{s}}\right)^{\frac{1-\alpha}{\alpha}}=\mathrm{a}_{\mathrm{c}}\left(\frac{\phi^{\alpha-1} \alpha \beta}{\alpha \mathrm{s} \beta+(1-\mathrm{s})(1+\beta)}\right)^{\frac{1-\alpha}{\alpha}}\left[1-\varepsilon \frac{(1-\mathrm{s})(1+\beta)}{\alpha \mathrm{s} \beta+(1-\mathrm{s})(1+\beta)}\left(1-\frac{\alpha \beta}{1+\beta}\right)\right]
$$

Comparing (B10) to (A21) above yields that South's growth rate is strictly higher when South gives an export subsidy than under free trade. 
Similarly for North, the goods markets clearing conditions imply:

$$
\begin{aligned}
& \frac{\mathrm{H}_{\mathrm{t}, \mathrm{t}}^{\mathrm{N}}}{\mathrm{H}_{\mathrm{t}}^{\mathrm{N}}}=\frac{(1-\varepsilon) \alpha}{1+\beta}+(1-\varepsilon)(1-\alpha) \\
& \mathrm{Y}_{\mathrm{k}, \mathrm{t}}^{\mathrm{N}}=\frac{\beta \mathrm{w}_{\mathrm{t}}^{\mathrm{N}} \mathrm{H}_{\mathrm{t}}^{\mathrm{N}}}{(1+\beta)}+\mathrm{E}_{\mathrm{k}, \mathrm{t}}^{\mathrm{N}} \\
& \Leftrightarrow \mathrm{Y}_{\mathrm{k}, \mathrm{t}}^{\mathrm{N}}=\frac{\beta \mathrm{w}_{\mathrm{t}}^{\mathrm{N}} \mathrm{H}_{\mathrm{t}}^{\mathrm{N}}}{(1+\beta)}+\frac{\beta \mathrm{w}_{\mathrm{t}}^{\mathrm{S}} \mathrm{H}_{\mathrm{t}}^{\mathrm{S}}(1-\mathrm{d})}{(1+\beta)} \\
& \Leftrightarrow\left(\phi^{\mathrm{t}}\right)^{\alpha}\left(\frac{\mathrm{K}_{\mathrm{k}, \mathrm{t}}^{\mathrm{N}}}{\mathrm{H}_{\mathrm{k}, \mathrm{t}}^{\mathrm{N}}}{ }^{1-\alpha} \mathrm{H}_{\mathrm{k}, \mathrm{t}}^{\mathrm{N}}=\frac{\beta}{1+\beta} \alpha\left(\phi^{\mathrm{t}}\right)^{\alpha}\left(\frac{\mathrm{K}_{\mathrm{k}, \mathrm{t}}^{\mathrm{N}}}{\mathrm{H}_{\mathrm{k}, \mathrm{t}}^{\mathrm{N}}}\right)^{1-\alpha} \mathrm{H}_{\mathrm{t}}^{\mathrm{N}}+\frac{\beta(1-\mathrm{d})}{1+\beta} \mathrm{P}_{\mathrm{t}-1, \mathrm{t}}^{\mathrm{S}} \alpha\left(\phi^{\mathrm{t}-1}\right)^{\alpha}\left(\frac{\mathrm{K}_{\mathrm{t}-1, \mathrm{t}}^{\mathrm{S}}}{\mathrm{H}_{\mathrm{t}-1, \mathrm{t}}^{1-\alpha}} \mathrm{H}_{\mathrm{t}}^{\mathrm{S}}\right.\right. \\
& \Leftrightarrow \frac{\mathrm{H}_{\mathrm{k}, \mathrm{t}}^{\mathrm{N}}}{\mathrm{H}_{\mathrm{t}}^{\mathrm{N}}}=\frac{\alpha \beta}{1+\beta}\left(1+\frac{\mathrm{H}_{\mathrm{t}}^{\mathrm{S}}}{\mathrm{H}_{\mathrm{t}}^{\mathrm{N}}}\left(1-\mathrm{s}+\frac{\alpha \beta}{1+\beta} \mathrm{s}\right)^{-\frac{1}{\alpha}}\right)
\end{aligned}
$$

Substituting (A21), (B11) and (B12) into the learning equation (4) for North, we have:

$$
\left(\mathrm{g}_{\mathrm{H}}^{\mathrm{N}}\right)^{\frac{1}{\delta}}\left(1+\mathrm{g}_{\mathrm{H}}^{\mathrm{N}}\right)^{\frac{1-\alpha}{\alpha}}=\left(\frac{\alpha \beta}{\phi(1+\beta)}\right)^{\frac{1-\alpha}{\alpha}}\left\{\mathrm{a}_{\mathrm{c}}\left[\frac{(1-\varepsilon) \alpha}{1+\beta}+(1-\varepsilon)(1-\alpha)\right]+\mathrm{a}_{\mathrm{k}} \frac{\alpha \beta}{1+\beta}\left(1+\frac{\mathrm{H}_{\mathrm{t}}^{\mathrm{s}}}{\mathrm{H}_{\mathrm{t}}^{\mathrm{N}}}\left(1-\mathrm{s}+\frac{\alpha \beta}{1+\beta} \mathrm{s}\right)^{-\frac{1}{\alpha}}\right)\right\}
$$

Equating the growth rates of North and South given by (B13) and (B10) respectively, yields:

$$
\frac{\mathrm{H}_{\mathrm{t}}^{\mathrm{s}}}{\mathrm{H}_{\mathrm{t}}^{\mathrm{N}}}=\frac{\mathrm{a}_{\mathrm{c}}\left(\frac{\phi^{\alpha}(1+\beta)}{\alpha s \beta+(1-\mathrm{s})(1+\beta)}\right)^{\frac{1-\alpha}{\alpha}}\left[1-\varepsilon \frac{(1-\mathrm{s})(1+\beta)}{\alpha s \beta+(1-\mathrm{s})(1+\beta)}\left(1-\frac{\alpha \beta}{1+\beta}\right)\right]-\mathrm{a}_{\mathrm{c}}(1-\varepsilon)\left(1-\frac{\alpha \beta}{1+\beta}\right)-\mathrm{a}_{\mathrm{k}} \frac{\alpha \beta}{1+\beta}}{\mathrm{a}_{\mathrm{k}} \frac{\alpha \beta}{1+\beta}\left[\frac{(1+\beta)}{\alpha s \beta+(1-\mathrm{s})(1+\beta)}\right]^{\frac{1}{\alpha}}}
$$

For a balanced growth path to exist we need:

i) $\frac{\mathrm{H}_{\mathrm{t}}^{\mathrm{S}}}{\mathrm{H}_{\mathrm{t}}^{\mathrm{N}}}>0$ 


$$
\Leftrightarrow \frac{a_{k}}{a_{c}}<1+\frac{\left(\frac{\phi^{\alpha}(1+\beta)}{\alpha s \beta+(1-s)(1+\beta)}\right)^{\frac{1-\alpha}{\alpha}}\left[1-\varepsilon \frac{(1-s)(1+\beta)}{\alpha s \beta+(1-s)(1+\beta)}\left(1-\frac{\alpha \beta}{1+\beta}\right)\right]-\left[1-\varepsilon\left(1-\frac{\alpha \beta}{1+\beta}\right)\right]}{\frac{\alpha \beta}{1+\beta}}(B 15)
$$

and:

ii) $\frac{\mathrm{H}_{\mathrm{t}-1, \mathrm{t}}^{\mathrm{N}}}{\mathrm{H}_{\mathrm{t}}^{\mathrm{N}}}>0 \Leftrightarrow \frac{\mathrm{H}_{\mathrm{t}-1, \mathrm{t}}^{\mathrm{N}}}{\mathrm{H}_{\mathrm{t}}^{\mathrm{N}}}=1-\frac{\alpha \beta}{1+\beta}\left(1+\frac{\mathrm{H}_{\mathrm{t}}^{\mathrm{s}}}{\mathrm{H}_{\mathrm{t}}^{\mathrm{N}}}\left[\frac{(1-\mathrm{d})}{(1-\mathrm{s})}\right]^{\frac{1}{\alpha}}\right)-\frac{(1-\varepsilon) \alpha}{1+\beta}-(1-\varepsilon)(1-\alpha)>0$

$\Leftrightarrow \frac{a_{k}}{a_{c}}>1+\frac{\left(\frac{\phi^{\alpha}(1+\beta)}{\alpha s \beta+(1-s)(1+\beta)}\right)^{\frac{1-\alpha}{\alpha}}\left[1-\varepsilon \frac{(1-s)(1+\beta)}{\alpha s \beta+(1-s)(1+\beta)}\left(1-\frac{\alpha \beta}{1+\beta}\right)\right]-1}{\frac{\alpha \beta}{1+\beta}+\varepsilon\left(1-\frac{\alpha \beta}{1+\beta}\right)}$

iii) Let $\mathrm{R}(\mathrm{s}) \equiv \frac{\mathrm{H}^{\mathrm{S}}}{\mathrm{H}^{\mathrm{N}}}(\mathrm{s}, \mathrm{d}(\mathrm{s}))$

$$
\mathrm{R}(\mathrm{s})=\frac{\mathrm{a}_{\mathrm{c}}\left(\frac{(1+\beta)}{\alpha \mathrm{s} \beta+(1-\mathrm{s})(1+\beta)}\right)^{\frac{1-\alpha}{\alpha}} \phi^{1-\alpha}\left[1-\varepsilon \frac{(1-\mathrm{s})(1+\beta)}{\alpha \mathrm{s} \beta+(1-\mathrm{s})(1+\beta)}\left(1-\frac{\alpha \beta}{1+\beta}\right)\right]-\mathrm{a}_{\mathrm{c}}(1-\varepsilon)\left(1-\frac{\alpha \beta}{1+\beta}\right)-\mathrm{a}_{\mathrm{k}} \frac{\alpha \beta}{1+\beta}}{\mathrm{a}_{\mathrm{k}} \frac{\alpha \beta}{1+\beta}\left[\frac{(1+\beta)}{\alpha \mathrm{s} \beta+(1-\mathrm{s})(1+\beta)}\right]^{\frac{1}{\alpha}}}
$$

Straightforward differentiation yields:

$\mathrm{R}^{\prime}(0)>0$ iff $\phi^{1-\alpha}<\frac{\mathrm{a}_{\mathrm{c}}(1-\varepsilon)\left(1-\frac{\alpha \beta}{1+\beta}\right)+\mathrm{a}_{\mathrm{k}} \frac{\alpha \beta}{1+\beta}}{\mathrm{a}_{\mathrm{c}} \alpha(1-\varepsilon)}$

and R"(s) $<0 \quad \forall \mathrm{s} \in(0,1)$. QED.

Proof of Proposition 4

As above, the growth rate of South is given by: 
$\left(\mathrm{g}_{\mathrm{H}}^{\mathrm{S}}\right)^{\frac{1}{\delta}}\left(1+\mathrm{g}_{\mathrm{H}}^{\mathrm{S}}\right)^{\frac{1-\alpha}{\alpha}}=\mathrm{a}_{\mathrm{c}}\left(\frac{\mathrm{P}_{\mathrm{t}-1, \mathrm{t}}^{\mathrm{N}} \alpha \beta(1-\mathrm{d})}{\phi(1+\beta)(1-\mathrm{s})}\right)^{\frac{1-\alpha}{\alpha}}\left[1-\varepsilon(1-\mathrm{d})\left(1-\frac{\alpha \beta}{1+\beta}\right)\right]$

When North is completely specialized the subsidy policy of South does not change the allocation of human capital to the production of the capital good and of the consumption good $t+1$ in the North. Hence, the growth rate of North is the same as under free trade:

$$
\left(\mathrm{g}_{\mathrm{H}}^{\mathrm{N}, \mathrm{T}}\right)^{\frac{1}{\delta}}\left(1+\mathrm{g}_{\mathrm{H}}^{\mathrm{N}, \mathrm{T}}\right)^{\frac{1-\alpha}{\alpha}}=\left(\frac{\alpha \beta}{\phi(1+\beta)}\right)^{\frac{1-\alpha}{\alpha}}\left\{\mathrm{a}_{\mathrm{c}}\left[\frac{(1-\varepsilon) \alpha}{1+\beta}+(1-\varepsilon)(1-\alpha)\right]+\mathrm{a}_{\mathrm{k}}\left[\frac{\alpha \beta}{1+\beta}+\varepsilon\left(1-\frac{\alpha \beta}{1+\beta}\right]\right\}(\mathrm{B} 18\right.
$$

Equalizing both growth rates yields:

$$
\left(\frac{1-\mathrm{d}}{1-\mathrm{s}} \mathrm{P}_{\mathrm{t}-1, \mathrm{t}}^{\mathrm{N}}\right)^{\frac{1-\alpha}{\alpha}}=\frac{\mathrm{a}_{\mathrm{c}}\left[\frac{(1-\varepsilon) \alpha}{1+\beta}+(1-\varepsilon)(1-\alpha)\right]+\mathrm{a}_{\mathrm{k}}\left[\frac{\alpha \beta}{1+\beta}+\varepsilon\left(1-\frac{\alpha \beta}{1+\beta}\right)\right]}{\mathrm{a}_{\mathrm{c}}\left[1-\varepsilon(1-\mathrm{d})\left(1-\frac{\alpha \beta}{1+\beta}\right)\right]}
$$

For balanced growth to exist we need:

i) $\mathrm{P}_{t-1, t}^{\mathrm{N}} \leq \phi^{\alpha}$

$$
\Leftrightarrow \frac{a_{k}}{a_{c}} \leq \frac{\left(\frac{1-d}{1-s}\right)^{\frac{1-\alpha}{\alpha}} \phi^{1-\alpha}\left[1-\varepsilon(1-d)\left(1-\frac{\alpha \beta}{1+\beta}\right)\right]-(1-\varepsilon)\left(1-\frac{\alpha \beta}{1+\beta}\right)}{\left[\frac{\alpha \beta}{1+\beta}+\varepsilon\left(1-\frac{\alpha \beta}{1+\beta}\right)\right]}
$$

or substituting d(s) using (B9)

$\Leftrightarrow \frac{a_{k}}{a_{c}} \leq 1+\frac{\left(\frac{(1+\beta)}{\alpha s \beta+(1-s)(1+\beta)}\right)^{\frac{1-\alpha}{\alpha}} \phi^{1-\alpha}\left[1-\varepsilon \frac{(1-s)(1+\beta)}{\alpha s \beta+(1-s)(1+\beta)}\left(1-\frac{\alpha \beta}{1+\beta}\right)\right]-1}{\left[\frac{\alpha \beta}{1+\beta}+\varepsilon\left(1-\frac{\alpha \beta}{1+\beta}\right)\right]}$

and:

ii) $\mathrm{P}_{\mathrm{t}-1, \mathrm{t}}^{\mathrm{S}} \geq 1$ 


$$
\Leftrightarrow \frac{a_{k}}{a_{c}} \geq 1+\frac{\left[\frac{(1-s)(1+\beta)}{\alpha s \beta+(1-s)(1+\beta)}\right]^{\frac{1-\alpha}{\alpha}}\left[1-\varepsilon \frac{(1-s)(1+\beta)}{\alpha s \beta+(1-s)(1+\beta)}\left(1-\frac{\alpha \beta}{1+\beta}\right)\right]-1}{\left[\frac{\alpha \beta}{1+\beta}+\varepsilon\left(1-\frac{\alpha \beta}{1+\beta}\right)\right]}
$$

Note that this inequality is automatically satisfied by Assumption 4.

Finally, we get from the goods market clearing condition for capital goods in North:

$$
\begin{aligned}
& \left(\phi^{\mathrm{t}}\right)\left(\frac{\mathrm{K}_{\mathrm{k}, \mathrm{t}}^{\mathrm{N}}}{\phi^{\mathrm{t}} \mathrm{H}_{\mathrm{k}, \mathrm{t}}^{\mathrm{N}}}\right)^{1-\alpha} \mathrm{H}_{\mathrm{k}, \mathrm{t}}^{\mathrm{N}}=\frac{\beta}{1+\beta} \alpha \phi^{\mathrm{t}}\left(\frac{\mathrm{K}_{\mathrm{k}, \mathrm{t}}^{\mathrm{N}}}{\phi^{\mathrm{t}} \mathrm{H}_{\mathrm{k}, \mathrm{t}}^{\mathrm{N}}}\right)^{1-\alpha} \mathrm{H}_{\mathrm{t}}^{\mathrm{N}}+\frac{\beta(1-\mathrm{d})}{1+\beta} \frac{\mathrm{P}_{\mathrm{t}-1, \mathrm{t}}^{\mathrm{N}}}{1-\mathrm{s}} \alpha \phi^{\mathrm{t}-1}\left(\frac{\mathrm{K}_{\mathrm{t}-1, \mathrm{t}}^{\mathrm{S}}}{\phi^{\mathrm{t}-1} \mathrm{H}_{\mathrm{t}-1, \mathrm{t}}^{\mathrm{S}}}\right)^{1-\alpha} \mathrm{H}_{\mathrm{t}}^{\mathrm{S}} \\
& \Leftrightarrow \frac{\mathrm{H}_{\mathrm{k}, \mathrm{t}}^{\mathrm{N}}}{\mathrm{H}_{\mathrm{t}}^{\mathrm{N}}}=\frac{\alpha \beta}{1+\beta}\left(1+\frac{\mathrm{H}_{\mathrm{t}}^{\mathrm{S}}}{\mathrm{H}_{\mathrm{t}}^{\mathrm{N}}} \frac{\mathrm{P}_{\mathrm{t}-1, \mathrm{t}}^{\mathrm{N}} \frac{1}{\alpha}}{\phi}\left[\frac{(1-\mathrm{d})}{(1-\mathrm{s})}\right]^{\frac{1}{\alpha}}\right) \\
& \Leftrightarrow \frac{\mathrm{H}_{\mathrm{t}}^{\mathrm{s}}}{\mathrm{H}_{\mathrm{t}}^{\mathrm{N}}}=\frac{\phi \varepsilon\left(1-\frac{\alpha \beta}{1+\beta}\right)\left\{\mathrm{a}_{\mathrm{c}}\left[1-\varepsilon \frac{(1-\mathrm{s})(1+\beta)}{\alpha \mathrm{s} \beta+(1-\mathrm{s})(1+\beta)}\left(1-\frac{\alpha \beta}{1+\beta}\right)\right]\right\}^{\frac{1}{1-\alpha}}}{\frac{\alpha \beta}{1+\beta}\left\{\mathrm{a}_{\mathrm{c}}\left[\frac{(1-\varepsilon) \alpha}{1+\beta}+(1-\varepsilon)(1-\alpha)\right]+\mathrm{a}_{\mathrm{k}}\left[\frac{\alpha \beta}{1+\beta}+\varepsilon\left(1-\frac{\alpha \beta}{1+\beta}\right)\right]\right\}^{\frac{1}{1-\alpha}}}
\end{aligned}
$$

Comparing (B22) and (A36), we observe that the relative size of South increases in the presence of the export subsidy compared to the free trade equilibrium. QED 